\title{
Collective Agreements and the Law of Contracts
}

Clyde W. Summers†

A "collective bargain" is itself a "contract"; but it is a contract of a very special kind....

Corbin on Contracts $§ 1420$

Professor Corbin relegated collective agreements to the periphery of contract law. His treatise briefly sketched the rights and duties created by collective agreements in a single section, placed without explanation in the chapter on "Illegal Contracts," and throughout the work the application of contract rules and principles to collective agreements was either casually mentioned or wholly ignored. ${ }^{1}$ Professor Corbin's justification for this neglect was that collective agreements were only marginally relevant to the central concerns of his treatise:

A collective bargain differs very greatly from the ordinary bargain of commerce, the parties to which are comparatively few, and the subject matter and purposes of which are generally very limited. The collective bargain has many features of a fundamental organizing statute, whose broad provisions control, in some degree, the activities of many individuals who may have had little or no part in its drafting and who may even have been bitterly opposed to the draftsmen. The collective bargainers cannot foresee all of the problems that are sure to arise and cannot provide for the innumerable details of the future administration of the bargain. . . . This treatise does not attempt the analysis and discussion of collective bargains. They cannot be treated with advantage separately from the general subject of Labor Relations and Labor Legislation. $^{2}$

Professor Corbin was not alone in his view of collective agreements as only distantly related to contracts proper. Dean Shulman, in his famous Holmes Lecture, "Reason, Contract and Law in Labor Relations,"3 acknowledged that collective agreements are made with the

$\dagger$ Garver Professor of Law, Yale Law School. B.S. 1939, J.D. 1942, Illinois; LL.M. 1946, Columbia.

1. A few brief sentences categorize collective agreements as third party beneficiary contracts, with the employee as donee beneficiary. See $4 \mathrm{~A}$ A. CorbIN, Contracts \& 781 , at 72, \& 782, at 83-84 (1962) [hereinafter cited as CoRBIN]. The rights of the union and the individual employee are briefly stated in footnotes. $I d$. $\$ 812 \mathrm{n.19}, \S 814 \mathrm{n} .55$. A few other sentences reject categorizing collective agreements as "joint" or "joint and several" contracts and cast them into outer darkness with these words:

Great bargaining transactions such as these, of great variety among themselves, have not yet received clear analysis. . . This remains for the future, to be determined by legislation, perhaps by conflict.

Id. \& 923 , at 697 .

2. 6A CorbIN § 1420, at 343 (1962).

3. 68 Harv. L. Rev. 999 (1955). 
expectation that both sides will respect them as binding commitments and that "[i]n the business world such commitments are called contracts. ... [ $\mathrm{T}]$ he collective labor agreement itself comes to be called the contract even by the workers ...."4 Nevertheless Dean Shulman rejected the proposition that the law should treat collective agreements as contracts and vigorously argued that legal enforcement was incompatible with the system of self-government contemplated by the collective agreement. ${ }^{5}$ Other writers in labor law have emphasized the difference between collective agreements and ordinary contracts, ${ }^{6}$ and labor arbitrators have studiously shunned looking either to treatises or to the Restatement of Contracts for guidance or even quotable authority. Although Section 301 of the Labor Management Relations Act has made collective agreements legally enforceable in the federal courts, ${ }^{7}$ the Supreme Court has reechoed the litany that "a collective agreement is not an ordinary contract" 8 and that the substantive law should be fashioned "from the policy of our national labor laws,"9 not simply drawn from traditional contract law.

The customary distinction between collective agreements and "ordinary contracts" assumes that there is a relevant legal category of "ordinary contracts"-as distinguished from, I suppose, "special contracts." It further assumes that the law of contracts is, and should be, centrally concerned with "ordinary contracts." From these two premises is drawn

4. Id. at 1001 .

5. It is ironic-and significant-that Professor Corbin and Dean Shulman, who for years were colleagues on the same faculty and whose philosophies of contracts and collective agreements followed largely parallel paths, should have reinforced each other so little. Professor Corbin, in a footnote to his treatise, quoted at length from Professor Shulman. 6A CoRBIN $\S 1420 \mathrm{n} .71$ (1962). But there is no hint that either recognized any basic similarity in their approach to the contracts with which each dealt. They epitomized the estrangement of contract lawyers and labor lawyers. Professor Corbin treated collective agreements as irrelevant to the main body of contract law, perhaps because he disliked the collective bargaining process and distrusted arbitration ("Battles have been fought for the system called 'collective bargaining'; but from the employer's standpoint a collective bargain has sometimes been found to be an illusion." 1 Corsin $\S 2$, at 3 (1963).); and Dean Shulman treated contract law as irrelevant to collective agreements because he disliked legal intervention and distrusted the courts. See Shulman, Reason, Contract, and Law in Labor Relations, 68 Harv. L. Rev. 999 (1955); H. Shulman, Preface to OPINIONS OF THE UMPIRE FORD MOTOR Co.-UAW-CIO 1943-1946 (1946). Each within his own favored forum viewed the contractual process from much the same perspective and perceived the role of adjudication in much the same terms, but neither drew support or insight from the other. Indeed, they scarcely recognized their kinship.

6. See, e.g., Cox, The Nature of The Collective Bargaining Agreement, 57 Mich. L. Rev. 1 (1958); St. Antoine, Contract Enforcement and the Courts, 15 LAB. L.J. 583 (1964); Rice, Collective Agreements in American Law, 44 Harv. L. Rev. 572 (1931); Krules, The Present Status of Collective Labor Agreements, 51 HARv. L. Rev. 520 (1938); Chamberlain, Collective Bargaining and the Concept of Contract, 48 Colum. L. REv. 829 (1948).

7. 61 Stat. 156 (1947), 29 U.S.C. \& 185 (1964).

8. John Wiley \& Sons v. Livingston, 376 U.S. 543, 550 (1964), restating the analysis of United Steelworkers v. Warrior \& Gulf Navigation Co., 363 U.S. 574, 578-80 (1960).

9. Textile Workers Union v. Lincoln Mills, 353 U.S. 448, 456 (1957). 
the concluding assumption that the legal principles applicable to "ordinary contracts" have limited relevance to collective agreements and that legal principles developed for collective agreements have little relevance for the rest of the law of contracts. Obviously, a manufacturer's bill of sale looks quite unlike his collective agreement, and legal rules for horse trading are quite inadequate for collective bargaining. But it is not obvious that bargains such as bills of sale should be the central concern of contract law, or that the only contract principles worth pursuing can be illustrated by hypotheticals about the sale of "my horse, Bob."10

My purpose here is to submit three broad propositions concerning the relationship of collective agreements to contract law. The viewpoint is inescapably that of a labor lawyer who abandoned teaching contracts even before Professor Corbin published his treatise. Nevertheless, the propositions have far more significant implications for the law of contracts generally than for the legal rules governing collective agreements. They are as follows:

First, a collective bargain clearly "differs greatly from the ordinary bargain of commerce," but collective agreements are a part of the mainstream of contracts and cannot be relegated to the periphery of contract law.

Second, the legal rules governing everyday commercial contracts can contribute little but mischief when applied to collective agreements, but the basic principles of contract-particularly those so forcefully articulated by Professor Corbin-can make valuable contributions to the law of collective agreements.

Third, while we may gain little insight into collective agreements by looking upon them as contracts, we can achieve significant insights into the nature of the law of contracts by viewing it from the perspective of collective agreements.

\section{The Collective Agreement as a Contract}

No one doubts that a collective agreement is a "contract," no matter which of many definitions of that term one selects. The question is not

10. The author has himself added his voice to the litany. "The Collective Agreement differs as much from a common contract as Humpty Dumpty differs from a common egg." Summers, Judicial Review of Labor Arbitration: Alice Through The Looking Glass, 2 Buff. L. REv. 1, 17 (1952). There is no intention to recant here, for Humpty Dumpty was an egg, even though he might not have been recognized as such by a chicken. The point here is that hens are not the only creatures who produce eggs, and indeed that the common egg is not necessarily the most important or most interesting of all eggs. 
whether collective agreements are contracts, but how much they are unlike other contracts and whether this makes them somehow less contractual in character. More specifically: in what particular respects are collective agreements unique, and how does their uniqueness affect their contractual character?

\section{A. The Uniqueness of Collective Agreements}

\section{Multiplicity of Parties and Complexity of Provisions}

Even the simplest collective agreement creates a three-sided relationship between union, employer, and employees; in many agreements the union and the employers may themselves be multiple parties as well. A national agreement between the Auto Workers and General Motors covers hundreds of thousands of employees in dozens of local unions, and the Central States Agreement of the Teamsters binds hundreds of employers and their employees. The substantive terms of the collective agreement may simply define basic terms of wages and hours, but the agreement more commonly prescribes complex rules regulating nearly every aspect of the employment relation, even to the size of work crews, subcontracting, maternity leave, and retirement rights. Multiple plant or multiple employer agreements, themselves complex, are normally supplemented by local or individual employer agreements which modify or further elaborate the provisions of the master agreement.

Such "great bargaining transactions"11 are obviously much more complicated than ordinary contracts for the sale of goods, lease agreements, or employment contracts. They are also far more difficult to analyze than a life insurance policy to pay a named beneficiary, or a surety bond to secure performance of a construction contract. Collective agreements, however, are not unique in having multiple parties and complex provisions. Indeed, such wide-reaching and multi-faceted contractual arrangements are commonplace in our intricately organized society. Consider, for example, the group insurance and pension plans which exist outside collective bargaining. The TIAA insurance and pension system for professors is scarcely a simple bilateral structure, and even more complex are the interlaced rights and duties of doctors, hospitals, group insurers, and covered individuals under Blue Cross hospital insurance. Consider also articles of agreement regulating housing cooperatives, farmers' marketing associations, and stock exchanges;

11. Note 1 supra. 
or negotiated contracts for the sale or merger of corporations involving the exchange of securities. The complex character of collective agreements does not make them unlike all other contracts, but instead reveals their kinship to certain kinds of agreements to which the law of contracts has always been assumed to apply.

\section{Incompleteness of Terms and Lack of Agreement}

Because of the diverse congeries of matters covered by a collective agreement and the practical need for a readable and reasonably concise document, a written agreement cannot possibly provide for the myriad of variant situations which might arise, even if they could be foreseen. Because of the pressures to reach a settlement, the parties may push aside potential problems in the hope that they will never become real, avoid clarifying language or intent lest it disclose latent disagreement, and deliberately paper over differences with studied ambiguities which leave each party with the hope, or at least the claim, that it has gained its point. The end result is a document with broad rules, a miscellany of gaps, unclear language, and unsettled issues. To the parties it represents agreement, even though they know that it is only the gateway to resolution of remaining disagreements.

Such uncertain and incomplete agreements might indeed make some real estate dealers or bank vice-presidents cringe, but collective agreements are not for that reason strangers to the world of contracts. Construction contracts, for all of their elaborateness, leave many terms unstated and are often based on the architect's projection of what is feasible and desirable. As unforeseen problems arise or design changes become necessary, the contract is adjusted or renegotiated. ${ }^{12}$ Long term suppliers' contracts often leave important terms indefinite or unsettled, ${ }^{13}$ ship charters may be incomplete, dealer franchises may do little more than state general rules for conducting the relationship, ${ }^{14}$ and articles of partnership may limit themselves to allocating the profit shares without even stating how profits shall be computed or when they shall be distributed. Indeed, practically every ongoing business relationship based on contract has, in a greater or lesser degree, this quality of incompleteness.

12. Sweet \& Sweet, Architectural Cost Predictions: An Institutional Analysis, 56 CALIF. L. REv. 996 (1968).

13. Note, Requirements Contracts: Problems of Drafting and Construction, 78 HARv. L. REv. 1212 (1965).

14. See S. Macaulay, Law and the Balance of Power; The Automobile ManuFacturers AND THeir Dealers (1966). 
Disagreements are often papered over or ignored in commercial transactions as well as in collective bargains, and for much the same reasons. In the "battle of forms," purchasing agents order on their purchase forms and sellers accept on their own acknowledgmentof-order forms, although the terms and conditions printed on the back of the two forms are commonly inconsistent. ${ }^{15}$ Important transactions are often concluded by brief letters or telephone calls; contingencies, even foreseeable ones, are not provided for; and details may be omitted to be filled in as conditions require. ${ }^{16}$ The reasons have been suggested by Professor Macaulay:

If one side insists on a detailed plan, there will be delay while letters are exchanged as the parties try to agree on what should happen if a remote and unlikely contingency occurs. In some cases they may not be able to agree at all on such matters and as a result a sale may be lost to the seller and the buyer may have to search elsewhere for an acceptable supplier. ${ }^{17}$

The pressures to close the transaction even though there is not complete agreement may be as great or greater in the commercial than in the collective bargaining context, at least for one of the parties. In collective bargaining, although open disagreement postpones settlement, the parties may extend an existing agreement until the issue is resolved; even a strike only temporarily interrupts the relationship. In business transactions, however, open disagreement may totally destroy the business relationship, with one of the parties finding more compliant persons with whom to deal.

\section{Compulsory Character of the Bargaining Relationship}

Section 9(a) of the National Labor Relations Act ${ }^{13}$ articulates the fundamental principle underlying all of our collective bargaining statutes-that the union designated by a simple majority of the employees in the bargaining unit shall be the exclusive representative of all employees in the unit. Selection of a majority union establishes a bargaining relationship which is compulsory for both the employer and all individual employees. ${ }^{19}$ The employer is compelled to bargain with

15. See Note, Non-conforming Acceptances Under Sec. 2-207 of the Uniform Commercial Code: An End to the Battle of Forms, 30 U. CHI. L. REv. 540 (1963).

16. Macaulay, Non-Contractual Relations In Business: A Preliminary Study, 28 Ам. Soc. REv. 55 (1963).

17. Id. 64 .

18. 49 Stat. 453 (1935), as amended by 61 Stat. 141 (1947), 29 U.S.C. \& 159(a) (1964).

19. Medo Photo Supply Corp. v. NLRB, 321 U.S. 678 (1944); Weyand, Majority Rule in Collective Bargaining, 45 Colum. L. Rev. 556 (1945). 
the majority union to the exclusion of all others. He must meet with the union, consider its proposals, explain his response to those proposals, and make good faith efforts to reach an agreement, ${ }^{20}$ If an agreement is reached, he must be willing to crystallize that agreement in a written and signed document. ${ }^{21}$ The individual employee loses almost entirely his freedom to contract. He is barred from bargaining on his own behalf or through any other representative, and he is bound by the agreement made by the majority union even when he is not a member, prefers individual bargaining, and opposes the specific terms negotiated by the union. ${ }^{22}$

Such coercion admittedly seems foreign to our stereotype of the contractual relationship as involving mutual assent to agreed terms. Certainly a collective agreement cannot fit the mold of the common commercial contract freely bargained on the competitive market. But this does not deprive collective agreements of their contractual character nor demonstrate that they are unique, for the compulsion does not go to the root of the contracting process, nor is compulsion absent in many other kinds of contracts.

Although the law requires bargaining and channels the bargaining process, it does not compel agreement nor dictate the terms of settlement. ${ }^{23}$ The substantive terms are those negotiated and agreed to by the parties in a bargained exchange. ${ }^{24}$ Nor are the parties irretrievably tied to each other. If they cannot agree, the employer may, after bar-

20. NLRB v. Reed \& Prince Mfg. Co., 205 F.2d 191 (1st Cir. 1953); Cox, The Duty to Bargain in Good Faith, 71 HARv. L. REv. 1401 (1958); Smith, The Evolution of the "Duty to Bargain" Concept in American Law, 39 Mich. L. Rev. 1065 (1941).

21. H.J. Heinz Co. v. NLRB, 311 U.S. 514 (1941). These various elements of compulsory bargaining were crystallized into statutory language in Section $8(\mathrm{~d})$ when the Act was amended in 1947. 61 Stat. 142 (1947), 29 U.S.C. \& 158(d) (1964).

22. J.I. Case Co. v. NLRB, 321 U.S. 332 (1944); Weyand, Majority Rule in Collective Bargaining, 45 Colum. L. REv. 556 (1945).

23. Smith, The Evolution of the "Duty to Bargain" Concept in American Law, 39 Mich. L. REv. 1065 (1941); Wellington, Freedom of Contract and the Collective Bargaining Agreement, 112 U. PA. L. Rev. 467 (1964); Cox, The Duty to Bargain in Good Faith, 71 Harv. L. Rev. 1401 (1958).

24. The melange of legal rules surrounding collective bargaining and the use of economic force obviously affects the relative bargaining strength of the parties. Prohibiting secondary boycotts weakens the bargaining positions of some unions significantly; or to look at the other side of the coin, clauses permitting situs picketing, consumer boycotts, and "work preservation" strengthen the bargaining position of some unions. The legal rules on "quickie" or "hiccup" strikes, the right of employees to cross picket lines, and the right of strikers to reinstatement can be heavy weight on the bargaining scales. Even determinations of the appropriate bargaining unit and rules as to the timing of elections affect bargaining power. In this sense, the law does affect the substantive terms of the bargain, just as the anti-trust laws, resale price maintenance laws, price discrimination laws, and trade-mark laws affect the substance of commercial bargains. Nevertheless, both union and employer remain free to use their bargaining strength to seek substantive terms according to their own scale of priorities. 
gaining to impasse, change the terms and conditions of employment by unilateral action or individual bargaining. ${ }^{25}$ The union can strike, but the employer may then hire replacements, again establishing the terms of employment by unilateral action or individual bargaining. ${ }^{26}$ These measures have varying degrees of effectiveness, depending on the relative economic position of the parties. But the important point is that the collective agreement is the product of economic pressures, not legal compulsion. Nor does the law compel the individual to agree. It forecloses him from bargaining for different terms, but it does leave him the alternative, however hard it may be, of seeking work elsewhere if he is unwilling to work under the terms of the collective agreement.

Furthermore, collective agreements are not unique in being framed under legal compulsion. ${ }^{27}$ The ancient common law required innkeepers to take in the traveler ${ }^{28}$ and common carriers to accept shipments. ${ }^{29}$ The modern public utility's duty to provide service is defined by law, ${ }^{30}$ and automobile insurance companies may be compelled to accept their share of assigned risks. ${ }^{31}$ The individual telephone subscriber is as much foreclosed from bargaining as the individual employee and has even less freedom to contract elsewhere. Nor are the economic pressures to agree any less compelling in many other bargaining relationships. Monopoly or oligopoly positions - not at all uncommon in our economy-can preclude or closely limit certain bargaining alternatives. If a manufacturer fails to agree with the producer of a patented machine, the substitute may be even less satisfactory than strikebreakers hired by a struck employer. In many business relationships the parties may be as mutually dependent on each other as a union and an employer. Exclusive dealerships and sole sources of supply may create relationships which make any interruption far more costly to one or both parties than a strike. ${ }^{32}$

The compulsory character of union-employer bargaining cannot be

25. NLRB v. Crompton-Highland Mills, Inc., 337 U.S. 217 (1949); cf. Bowman, Employers' Unilaterial Action-An Unfair Labor Practice? 9 VAND. L. Rev. 487 (1956).

26. NLRB v. Mackay Radio \& Tel. Co., 304 U.S. 333 (1938); Note, Replacement of Workers During Strikes, 75 YALE L.J. 630 (1966).

27. See Lenhoff, The Scope of Compulsory Contracts Proper, 43 Colum. L. Rev. 587

(1943); Hale, Bargaining, Duress and Economic Liberty, 43 Colum. L. Rev. 603 (1943).

28. J. BEAle, THE LAW OF INNKEEPERS AND Hotels chs. VI-VIII (1906).

29. See I. REDfield, Carriers 108 (1869).

30. See Note, The Duty of a Public Utility to Render Adequate Service: Its Scope and Enforcement, 62 Colum. L. REv. 312 (1962).

31. See, e.g., Conn. Gen. Stat. ANN. \& 14-130 (Supp. 1969); ILl. Rev. Stat. ch. 951/2, § 7-501 (1957); OHio Rev. Code ANN. \& 4509.70 (1965).

32. Kessler, Automobile Dealer Franchises: Vertical Integration by Contract, 66 Yale L.J. 1135 (1957). 
ignored, nor should its importance be minimized. This characteristic of the bargaining process must shape the legal rules governing the collective agreement which results. But the collective agreement is not for this reason so unique that it should be considered a thing apart, for many other contractual relations are creatures of legal compulsion or are pressed upon the parties by compelling economic forces.

\section{Continuous Relationship with Successive Agreements}

In form, most collective agreements are for a fixed term; at the end of the term, the agreement expires and the parties negotiate a new agreement for another fixed term. In practice, however, the relationship continues unbroken from term to term. The parties understand that although successive agreements are discrete documents, they do not fragment the rights and duties they create into insulated time units. Seniority rights continue to accumulate, unbroken by successive agreements; ${ }^{33}$ vacation rights earned under one agreement are enjoyed under the next; ${ }^{34}$ and an employee discharged during one contract term may be reinstated by an arbitration proceeding held during the next contract term. ${ }^{35}$ Even though a strike interrupts production, it does not break the essential continuity of the relationship. During the strike, the parties may have few, if any, contractual obligations to each other. But when the strike is settled, the new agreement normally picks up where the old agreement left off, much as if there had been no strike. Seniority is not broken, accrued vacation or pension rights are not destroyed, and grievances in process continue on to arbitration.

Although successive agreements alter some of the terms of the relationship, most of the rights and duties, both substantive and procedural, customarily continue unchanged. Periodic negotiations are, in fact, not for the making of new agreements, but for modifications of the old. Nor do the parties consider an agreement as more than an interim settlement, a transitory stage in their continuing relationship. Even before accepting the terms of one agreement they may be looking forward to the demands to be made in the next negotiations. This char-

33. Seniority provisions can be altered by successive agreements, but in practice the changes are minor and infrequent. If the collective bargaining relation terminates so that the union no longer represents the employees, then seniority rights may disappear. See Aaron, Reflections on the Legal Nature and Enforceability of Seniority Rights, 75 HARv. L. REv. 1532 (1962); Blumrosen, Seniority Rights and Industrial Change: Zdanok v. Glidden Co., 47 MinN. L. Rev. 505 (1963).

34. NLRB v. Great Dane Trailers, Inc., 388 U.S. 26 (1967); Note, Treatment of Monetary Fringe Benefits and Post Termination Survival of the Right to Job Security, 72 YALE L.J. 162 (1962).

35. United Steelworkers v. Enterprise Wheel \& Car Corp., 363 U.S. 593 (1960). 
acteristic of the collective agreement as a periodic renegotiation of terms in a continuing relationship makes it quite unlike a simple sales contract, promissory note, or surety agreement which states the terms for a single transaction. But again, this does not make the collective agreement a stranger in the family of contracts. Periodic leases, subject to repeated renegotiation and renewal, may be used to regulate longterm rental arrangements. Continuing arrangements for lines of credit may be expressed in a succession of separate contracts. Franchises, dealerships, and requirements contracts may also establish continuing relationships which are modified by periodic renegotiation. ${ }^{36}$

There is no need to identify and describe further distinguishing characteristics of the collective agreement here. It should already be plain that although collective agreements differ greatly from "ordinary bargains of commerce," they are full members of the contract family. Many other contractual relationships also differ greatly from "ordinary bargains of commerce" and share one or more of the marked characteristics of collective agreements. The uniqueness of collective agreements is matched by the uniqueness of many other contracts, and none should be disowned as club-footed cousins simply because they are in some sense not "ordinary contracts."

\section{B. The Contractual Character of Collective Agreements}

From the social point of view, the collective agreement may have more "contractualness" 37 than many other bargained transactions. Professor Macaulay has measured contracts in terms of two distinct elements: (1) rational planning with provision for future contingencies, and (2) the existence or use of actual or potential legal sanctions. ${ }^{38}$

The collective agreement is pre-eminently an instrument of private planning, and its qualities of complexity and continuity reflect the importance of its planning function. It not only establishes rules governing the relations of union and employer but also enacts regulations governing the terms and conditions of employment of all the employees in the bargaining unit. Although its provisions seem general and incomplete, as they are continued from one contract to the next they

36. As a result of both state and federal statutes, the automobile manufacturer-dealer relationship has now become "a kind of compulsory contract; manufacturers must continue relationships with dealers unless a dealer has in some way violated a duty under the franchise." S. Macaulay, Law and the Balance of Power; The Automobile ManuFACTURERS AND TheIR DEALERS 198 (1966).

37. The term is Professor Macaulay's.

38. Macaulay, Non-Contractual Relations in Business: A Preliminary Study, 28 Ам. Soc. REv. 55 (1963). 
are supplemented by the common law of the shop, gaining explicitness through the parties' acceptance of practices, grievance settlements, and arbitration awards. Troublesome gaps are filled and disputes resolved by modifications in the agreement. Deliberate ambiguities may remain and unforeseen contingencies do arise, but the parties plan for these by creating a structured grievance procedure, customarily ending in arbitration, which will enable them to clarify the rules, adjust to changed conditions, and modify their relationship as problems arise. "The trade agreement thus becomes, as it were, the industrial constitution of the enterprise." 39 When measured against the complexity of the relationship they govern, collective agreements provide more detailed planning and make more complete provision for contingencies, both foreseen and unforeseen, than many of the commercial contracts with which they are often unfavorably compared.

The second element of "contractualness"-the existence or use of legal sanctions-is more difficult to measure in collective agreements. The received tradition is that compliance with collective agreements does not rest upon legal compulsion but upon the parties' recognition of their moral responsibility and their mutual self-interest in good faith dealing. Whether this is any more true for collective agreements than for other contractual relations is not at all clear. Certainly, legal sanctions for breach of collective agreements do exist and are used. Under Section 301 of the Labor Management Relations Act collective agreements are legally enforceable in both federal and state courts, and most collective agreements are so drawn as to make the full range of legal sanctions available. ${ }^{40}$ Court actions to compel arbitration, to enforce awards, for back pay, or for damages due to strikes are reported daily, and NLRB procedures to remedy breaches of contract are increasingly invoked. ${ }^{41}$ The parties, in negotiating and administering their agreement, cannot help but be aware of the available legal sanctions and inevitably consider using them to compel compliance, at least as a last resort. Even though these legal sanctions may be seldom used, they significantly affect the relationship in many instances.

Enforcement of collective agreements is admittedly largely through grievance arbitration, but this method is, at most, only one step re-

39. NLRB v. Highland Park Mfg. Co., 110 F.2d 632, 638 (4th Cir. 1940).

40. For exceptional clauses foreclosing the right to sue, see BurEaU of National Affairs, Collective Bargaining Negotiations and Contracts 77:155 (1967). The most noted example is the collective agreement between the United Mine Workers and the Bituminous Coal Operators' Association, id.

41. NLRB v. Strong, 390 U.S. 920 (1969); NLRB v. C \& C Plywood Corp., 385 U.S. 421 (1967); C \& S Indus., Inc., 158 N.L.R.B. No. 43, 62 L.R.R.M. 1043 (1966). 
moved from legal sanctions. Arbitration is, in many respects, a surrogate for the courts. It is a process of adjudication by third persons when the parties to the agreement cannot agree on its meaning or are unwilling to overlook violations. ${ }^{42}$ It interprets and applies the agreement, determines the scope and seriousness of the violation, and prescribes the remedial action to be taken. When an arbitration clause is present in the collective agreement the process can be judicially compelled, ${ }^{43}$ the procedure is subject to judicial supervision, ${ }^{44}$ and the award can be judicially enforced. That only a small fraction of grievances end in arbitration does not measure the importance of this method of enforcement. The process of grievance settlement, indeed the nature of the entire relationship, is entirely different when arbitration is available as a last resort. Moreover, arbitration is not always relegated to last-resort status but is often used as an integral part of administering the agreement. If we view grievance arbitration as a form of legal enforcement, in fact, we might well conclude that the collective agreement is among the most litigation-prone of all contractual relations. Anyone familiar with labor arbitration cannot help but be impressed-or more accurately, depressed-by the large number of litigated issues which are trivial and worthless, which represent no conflict of principle but only a clash of personalities. Many cases are brought to arbitration without any serious efforts to settle, or adjudication is sought because the officers of the union, or management, or both, are unwilling to accept responsibility for agreeing to an inescapable result. Businessmen who insisted on litigating such matters with customers or suppliers would soon have few of either, but the compulsory quality of the collective bargaining relation binds the parties together regardless of their litigiousness. In many collective bargaining relationships the loss of goodwill is counted of little consequence and resort to arbitration is considered the normal and acceptable way of conducting affairs. "Contractualness" in terms of enforcement through a process of litigation and adjudication then becomes the most marked characteristic of the collective bargaining relationship.

Implicit in the foregoing has been the proposition that contracts are not all alike. They have differences, substantial and important differences. Collective agreements are not "ordinary contracts," but

42. For a comparison of the role of an arbitrator and a judge in applying and enforcing contracts, see Fuller, Collective Bargaining and the Arbitrator, in Collective Bargaining AND THE ARBitrator's Role 8 (1962).

43. Textile Workers Union v. Lincoln Mills, 353 U.S. 448 (1957).

44. United Steelworkers v. Enterprise Wheel \& Car Corp., 363 U.S. 593 (1960). 
neither are construction contracts, lease purchase agreements, requirements contracts, dealership franchises, insurance policies, stock certificates, and a lawyer's retainer. The term "contract" describes a family of relationships, but within that family are many genuses, and the collective agreement is one genus in that family. It is not some fearful and marvelous mutation, to be treated as an outcast or a stranger; it is a full-fledged contract which bears in marked degree the essential elements of contractualness.

II. The Usefulness of Contract Law for Collective Agreements: Rules, Tools, and Doctrines

Once it is recognized that collective agreements do belong within the contract family, logic would seem to require that the law of contracts be applicable to them, and that the legal rules and principles developed to govern contractual relations generally should be useful in defining the rights and duties created by collective agreements. Logic, however, cannot erase the stubborn fact that these rules and principles will often make mischief if imported into the collective bargaining context. There is a core of truth in the assertion that collective agreements are not "ordinary contracts," and therefore that "ordinary contract law" is not applicable to them. The drawing of analogies between collective agreements and "ordinary contracts" is no substitute for specific consideration of the extent to which the rules and principles of contract law are appropriate and useful in application to collective agreements.

To begin with, contract law gives no useful guidance in defining rights and duties under collective agreements if contract rules are applied or ignored from case to case on an ad hoc basis. We gain nothing if courts appeal to "ordinary principles of contract law" when the question is whether an oral agreement is effective before the written contract is signed," ${ }^{45}$ but then find "no satisfactory solvent in conventional contract or corporate law" when the question is whether the collective agreement survives a corporate merger. ${ }^{46}$ Such hopscotch applications serve only to display contract law as a mistress of convenience, capable

45. Genesco, Inc. v. Joint Council 13, United Shoe Workers, 341 F.2d 482, 489 (2d Cir. 1965), discussed in Note, Section 301(a) and the Federal Common Law of Labor Agreements, 75 Yale L.J. 877 (1966); United Steelworkers v. C.C.I. Corp., 395 F.2d 529, 533 (10th Cir. 1968).

46. Bath Iron Works Corp. v. Bath Marine Draftsmen's Ass'n, 393 F.2d 407 (1st Cir. 1968), following the Supreme Court's similar language and result in John Wiley \&. Sons v. Livingston, 376 U.S. 543 , 550 (1964). 
of troublemaking by jealous insistence on being recognized at the wrong time. It is clear, however, that certain types of contract rules are more susceptible to such hit or miss application than others, and hence are more likely to cause difficulty.

First, contract rules which attempt to define with some specificity or detail rights and duties of parties are largely useless and often misleading when applied to collective agreements. These rules may be distilled from court decisions-more accurately, from those decisions which contract scholars read-but these decisions may involve types of contracts which are significantly different from collective agreements. Professor Corbin has ten sections on employment contracts, all of them studded with rules quite contrary to those developed under collective agreements. ${ }^{47} \mathrm{He}$ states, for example, that willful disobedience of reasonable orders is grounds for discharge ${ }^{48}$ but thousands of arbitration decisions have held otherwise, finding that insubordination justified only reprimand or disciplinary lay-off. Again, Professor Corbin states that an employee's refusal to do work which is not a part of his job is not wrongful, ${ }^{49}$ but arbitrators have almost uniformly held that refusal to obey such orders makes the employee liable for discipline. He must obey and file a grievance unless there is serious risk to his health or safety. The section on term of service does not even mention the principle of seniority which permeates most collective agreements. ${ }^{50}$ Professor Corbin, to be sure, accurately summarized the working rules governing those employment contracts which generate court decisions - professional and white collar employments for a term and not subject to collective agreements. But most industrial employment is at will, with security provided by collective agreements, and employments at will produce few court decisions. Not surprisingly, the legal rules developed to regulate one type of employment relationship are illsuited to regulate the other.

Second, even contract rules cast in broader terms as being generally applicable to various types of contracts may be misconceived and lead to unwanted results when applied to collective agreements. Professor Corbin treats collective agreements as contracts made for the benefit of third persons, and quite properly so. ${ }^{51}$ The union and the employer clearly intend to provide benefits for the individual employees, and

47. 3A CoRbIN $\$ \S 674-83$ (1962).

48. Id. \& 679 .

49. Id. \& 683 .

50. Id. \& 684 .

51. Id. $\$ \S 781$ n.35, 782 nn.17-18, 
the individual employees acquire legally enforceable rights under the agreement. ${ }^{52}$ But some of the general rules developed for other third party beneficiary contracts simply do not fit the collective bargaining relation. Black letter law tells us that "[a] donee beneficiary . . . may ... render the duty to himself inoperative from the beginning by disclaimer,"53 and Professor Corbin states flatly, "There is no question that ... a release sealed and delivered by him [the beneficiary], a substituted contract or novation, an accord and satisfaction, may all be operative to discharge his right against the promisor." ${ }^{54}$ This rule, however, cannot be applied to collective agreements. As the Supreme Court said twenty-five years ago, "the individual contract cannot be effective as a waiver of any benefit to which the employee otherwise would be entitled under the trade agreement."55 To permit individual employees to disclaim benefits or to modify by novation or accord and satisfaction would defeat the fundamental purposes of the collective bargaining statutes which provide the legal framework for collective agreements.

Black letter law also tells us that the rights of the donee beneficiary cannot be discharged or modified by the contracting parties unless the power to do so is reserved, and the reservation must ordinarily be expressed in specific terms. ${ }^{56}$ Unions and employers, however, must have the power mutually to terminate or amend their agreements. Otherwise, agreements for terms long enough to provide stability in the bargaining relationship might impose an unbearable rigidity upon the union-employer relationship. The courts have never questioned the parties' power to amend the collective agreement and alter the rights of the employee even though this power is not expressly reserved, at least so long as the amendment is made according to the same procedure as the original agreement. ${ }^{57}$ The power of the union to surrender or compromise the beneficial rights of an individual member by settlement of his grievance is less clear, but at least the union can foreclose the individual's rights by good faith and non-arbitrary decisions as to the merits of particular grievances. ${ }^{58}$ The union's power does not, however, depend on any express reservation in the collective agree-

52. Smith v. Evening News Ass'n, 371 U.S. 195 (1962).

53. Restatement of Contracts \& 137 (1932).

54. 4 CORBIN \& 811, at 235 (1962).

55. J.I. Case Co. v. NLRB, 321 U.S. 332, 338 (1944).

56. Restatement of Contracts \& 42 (1932); 4 Corbin \& 814 (1962).

57. See Humphrey v. Moore, 375 U.S. 335 (1964), particularly the separate opinions of Mr. Justice Goldberg and Mr. Justice Harlan.

58. Vaca v. Sipes, 386 U.S. 171 (1967). 
ment, but on the judicially conceived needs of the collective bargaining relation and of grievance settlement procedures. ${ }^{59}$

These general third party beneficiary rules do not work when applied to collective agreements for the simple reason that they were distilled largely from court decisions dealing with quite different types of third party transactions. The donee beneficiary cases which provide the precedents are heavily weighted with two types of transactionsintra-family gifts and designation of beneficiaries of life insurance. ${ }^{60}$ The resulting legal rules, rooted in part in the ancient law of gifts, ${ }^{61}$ are shaped to fit the facts before the court, and only with blind luck will they fit other types of transactions. Indeed, Professor Corbin found it necessary to tailor third party beneficiary principles to fit liability insurance, ${ }^{62}$ and declared them quite inadequate to solve problems posed by group insurance. ${ }^{63}$

Such rules fail to fit collective agreements because they are cast in broader terms than either precedent or practical need justifies. Whatever may be the core of common principles applicable to all forms of third party beneficiary contracts-and I suspect it is a small but solid core-most of the supposedly general rules are not in fact generally applicable. The interrelation of rights and duties of the three parties as articulated by the courts must reflect the special character of the transaction in question. It would be startling, indeed frightening, if the same legal rules defined the insurance company-insured-beneficiary relationship, the water company-city-homeowner relationship, and the employer-union-employee relationship. The complex of rights and duties interrelating the employer, the union and the individual employee

59. On the other side of the coin, black letter law states that a promisor can set up as a defense against the third party beneficiary, the failure by the promisee to perform conditions precedent on counterclaims against the promisee arising out of breaches by the promisee of his duties under the same contract. RESTATEMENT OF CoNTRACTs \& 140 (1932); 4 Corbin $\S 819$ (1951). But in Lewis v. Benedict Coal Corp., 361 U.S. 459 (1960), the Supreme Court had to repudiate Professor Corbin's statement of these rules. The employer, when sued for payments due to the pension and welfare fund, attempted to set off damages resulting from strikes in violation of the agreement. The Court refused to allow the setoff, declaring that this was "not a typical third party beneficiary contract," and pointing out that such a setoff would amount to the employer's recouping his losses from the union's breach by reducing the wages due to employees. This would run counter to the principle expressed in Section $301(\mathrm{~b})$ of the Taft-Hartley Act, 29 U.S.C. § 185(b) (1964), that judgments against a union should be enforceable only against the union and its assets and not against any individual member or his assets.

60. See 4 CoRbin § 782 (1951), and illustrations in Restatement of Contracts $\S 133$, $135,139,142$ (1932). Contracts within the family have historically been subject to special rules, or common rules have been rather specially applied. See McDowell, Contracts in the Family, 45 B.U.L. Rev. 43 (1965).

61. See 4 Corbin \& 811 , at 237 , § 814, at 254 (1962).

62. Id. \& 813 (Supp. 1964).

63. Id. § 814 , at $251-53$ (1962). 
must meet the practical needs of collective bargaining; it must reflect the union's statutory status as exclusive representative; and it must safeguard the individual from arbitrary collective action. Other third party beneficiary contracts undoubtedly have their institutional imperatives, their controlling legal framework, and perhaps their conflict between individual and collective rights. But the needs of each type of contract may dictate quite special rules. Through these varied sets of rules may well run some common threads or even working principles. But surely they are not the narrowly conceived rules which now pass for the law of third party beneficiary contracts.

Third, certain analytical constructs from the law of contracts may be of some use in analyzing rights and duties and in rationalizing decisions under collective agreements. For example, the distinctions between promises and conditions, ${ }^{64}$ or between total and partial breach ${ }^{65}$ may be helpful in defining the rights and duties of the parties. These analytical tools, however, give little real guidance to sound results. Indeed, if they are relied upon to provide more than a logical structure or verbal formulation of the results, they may be more misleading than helpful. ${ }^{66} \mathrm{~A}$ couple of not-so-hypothetical cases will illustrate the usefulness and limitation of contract law at this level.

A collective agreement provided that, "The employer shall give the union 48 hours' notice of all temporary lay-offs." Because of the urgent need to catch up on repairs and maintenance, the employer decided on Monday afternoon to shut down for the next two days, and so notified the union. The union filed a grievance claiming two days' pay for all the employees laid off on the grounds that the required notice was a condition precedent to the employer's right of lay-off. The employer contended that his obligation to give notice was a bare promise, and that its breach had caused only nominal damage because the employees were destined to lose two days' pay in any case. The question seems to be whether the notice requirement is characterized as a condition or as a bare promise, but we cannot, by asking which it is, determine the result. The inquiry must start at the other end and ask which result best reflects the parties' intent and fulfills their purposes. The distinction between promise and condition then becomes a device for articulating that result within a logical framework.

In another case, a collective agreement made with one employer re-

64. Restatement of Contracts $\S 260$ (1932).

65. Restatement of Contracts \& 313 (1932).

66. "You can give any conclusion a logical form. You always can imply a condition in a contract." Holmes, The Path of the Law, 10 HARv. L. REv. 457, 466 (1897). 
quiring payments into pension, welfare, and group insurance funds provided, "The union will not make an agreement more favorable to any other warehouse in the Port of New York, or in such event will simultaneously modify this agreement to conform therewith."67 The union then made agreements with other warehouses which did not require such payments. The first employer had various courses of action open to him. He could (a) sue the union for damages and to compel modification of the agreement; (b) refuse to make payments into the pension, welfare, and insurance funds; or (c) declare the collective agreement at an end. It may be helpful to analyze the problem in terms of whether the "most favored nation clause" was a promise, a condition precedent, or both; and if it was a condition, what promise of the employer was made conditional. This analysis may focus our attention on the variety of solutions available, but it does not tell us which solution is the most sensible. Nor do Restatement-type rules give much guidance. Choosing a solution requires more than simple inquiry into the parties' intent; it requires the weighing of a wide range of considerations, including the effect of the solution on the integrity of the pension fund, the need for protecting the employees' insurance rights, the financial responsibility of the union, the extent to which employees should suffer for the union's default, and the importance of maintaining the stability of the collective bargaining relationship. ${ }^{68}$ The language of "promise," "condition," or "promissory condition" provides the verbal formulation for expressing the solution, but the solution must be dictated by the institutional needs and social considerations radiating from the collective agreement as a planning transaction. ${ }^{69}$

Fourth, certain broad contract doctrines such as material breach and failure of consideration may similarly provide persuasive rationales for results. Again, however, they give little guidance in the choice of specific solutions. The doctrine of material breach seems to have substantive content and working guidelines, but these are largely illusory. For example, if a union strikes in violation of a no-strike clause

67. Erie Basin Terminal Warehouse Co. v. Warehousemens Local 976-4, 68 L.R.R.M. 2055 (S.D.N.Y. 1968). We put to the side here questions whether this provision violates the antitrust laws. See United Mine Workers of America v. Pennington, 381 U.S. 657 (1965).

68. See Lewis v. Benedict Coal Corp., 361 U.S. 459 (1960).

69. The familiar formula that the construction of the contract "depends on all of the circumstances of the case," appears to be little more than a device by which the court is able to achieve what it regards as the most just result under the circumstances of the case. Atiyah, Judicial Techniques and the English Law of Contracts, 2 OtTawa L. Rev. 337 (1968). 
in the agreement, the doctrine might be invoked as in Marathon Electric: ${ }^{70}$

$[\mathrm{T}]$ he prevention of strikes is one of the principal purposes of labor contracts and of the Act. A no-strike provision is "The chief advantage which an employer can reasonably expect from a collective labor agreement." The walkout was a material breach which justified the subsequent rescission of the contract by the Company. ${ }^{71}$

The logic is appealingly neat and persuasive-until one examines the result. In this case, the union had insisted that a two-cent wage increase provided for in the agreement be put into immediate effect. This demand, though improper, was not without rational basis. When the Company refused, the union called a meeting during working hours, causing a walkout. The Company then locked the plant gates, refused to allow any employees to return to work, and notified the union that because of the strike in breach of the collective agreement the Company was cancelling the agreement. The Company advertised for new employees and gave no priority to old employees, taking them back only as new applicants with no seniority. The result was a total disruption of the collective bargaining relation, destruction of employees' job security and seniority rights, and such serious aggravation of the dispute that labor peace became impossible. Yet the Company's response, the court held, had been proper because the walkout was a "material breach."

What the court failed to recognize is that the word "material," as used in the doctrine of "material breach," is not a synonym for "important" or "major," describing an objective quality. Instead, it is a word of art given content only by the results it describes. Thus the Restatement, after black lettering some "general principles based on inherent justice" says:

The question then to be answered is: Will it be more conformable to justice in the particular case to free the injured party, or, on the other hand, to require him to perform his promise, in both cases giving him a right of action if the failure to perform was wrongful. ${ }^{72}$

In applying the doctrine to collective agreements, the question is not whether prevention of strikes is the "principal purpose" of the contract or the "chief advantage" expected by the employer. The question is

70. Electrical Workers Local 1113 v. NLRB, 223 F.2d 338 (D.C. Cir. 1955).

71. 223 F.2d at 341 .

72. Restatement of Contracts $\$ 275$, comment $a$ (1932). 
whether allowing the employer to terminate the agreement will do justice between the employer, the union, and the employees, aid the continuing relations of the parties, promote the statutory purposes of collective bargaining, and protect the social interest in labor peace. Only when the weighing of all relevant considerations tips the balance in favor of those consequences which follow from allowing the employer to terminate is the strike a "material breach."

There are at least three dangers in the use of analytical tools or doctrines of contract law such as those just discussed. The first has already been made quite plain. Because they seem to provide guides for making decisions, they may divert attention from the essential inquiry, as in Marathon Electric. The court there did not even consider whether fairness between the parties, as well as institutional and social needs, might be better served by a different solution. The court did not weigh other alternatives, such as leaving the collective agreement in effect to stabilize the relationship and providing the employer with remedies in the courts for breach of contract and remedies before the NLRB for violation of Section 8(d) of the Labor Management Relations Act. Because the court was led into asking the wrong question, it was led to the wrong result.

The second danger is that these doctrines suggest either-or answers; the breach is either material or it is not and the two alternatives provide only two results. More carefully tailored solutions may be overlooked. In Mastro Plastics, ${ }^{73}$ the employer sought to supplant the incumbent union with a more friendly and compliant union. As a part of that effort, the employer discharged an employee who continued actively to support the incumbent union. This triggered a strike by other supporters of the incumbent union despite a broad no-strike clause in the collective agreement prohibiting "any strike or work stoppage." The Supreme Court held that in view of the statutory policies surrounding the agreement, the words "any strike" should not be read to prohibit strikes to protest employer unfair labor practices. Therefore, the strike did not violate the agreement. It has been urged that the Court, rather than violate the plain meaning of the words, should have held that the employer's frontal attack on the very existence of the bargaining representative was a material breach excusing the union from its no-strike obligation. ${ }^{74}$ But use of material breach analysis tends to force a choice between leaving the no-strike clause standing un-

73. Mastro Plastics Corp. v. NLRB, 350 U.S. 270 (1956).

74. Cox, The Legal Nature of Collective Bargaining Agreements, 57 Mich. L. Rev. 1, 18 (1958). 
touched or destroying it entirely. We ought at least to consider the advantages of the Court's intermediate solution of permitting the union to strike against grossly unfair labor practices while leaving the no-strike obligation otherwise intact. Material breach analysis does not foreclose this result, but does obscure its availability.

The third and most serious danger is that use of these common contract doctrines invites the borrowing of precedents from other contractual settings which may have involved quite different considerations. ${ }^{75}$ Even Professor Corbin has fallen into this trap. In Drake Bakeries, ${ }^{76}$ the employer rescheduled work because Christmas and New Years came on Fridays. The employees were told not to report on the Thursdays preceding the holidays but to report on the Saturdays following them. The union insisted that this rescheduling violated the collective agreement, and when discussions proved unfruitful, the employees refused to report on Saturday. The employer sued the union for damages for breach of the no-strike clause, and the union moved to stay the suit pending arbitration. Professor Corbin, extrapolating from non-labor cases, generalized that a party who repudiates an arbitration agreement or commits a breach "of a kind that destroys the end and aim of the arbitration provision itself" has no right to arbitration. He then argued that in collective agreements

[t]he purpose of the arbitration is to insure continuous production and avoid strikes; a strike is itself a breach (and repudiation) of the agreement to arbitrate. ${ }^{77}$

From this he concluded that the strike had defeated a vital purpose of

75. See, e.g., the dissenting opinion of Mr. Justice Frankfurter in Lewis v. Benedict Coal Corp., 361 U.S. 459, 471 (1960). It assumes that because "fairness and justice" usually require that in third party beneficiary contracts the promisor can set off against the beneficiary counterclaims he has against the promisee, the same result is required in collective agreements. But "fairness and justice" is not such a fungible concept, nor is it a tail attached to certain legal rules. An employee under a collective agreement, unlike most donee beneficiaries, is not an object of charity or bounteous generosity-he has to work for what he gets. The question is whether it is "fair and just," after he has done his work, to deduct from his paycheck or pension rights losses suffered by the employer due to strikes engaged in by other employees and tolerated by the union. It may be that some legal doctrines "represent an accumulation of tested wisdom ... bottomed upon notions of fairness and sound public policy, and it would be a foolish waste to climb the ladder all over again ...."Cox, The Legal Nature of Collective Bargaining Agreements, in University of Michigan Law School Summer Institute, Collective Bargaining and the LAw 121 (1958), quoted in the dissenting opinion at 476. But contract doctrines need to be constantly retested, for as Professor Corbin emphasized, they are never more than "working rules," and the need for retesting is imperative when those doctrines are to be applied to different types of transactions: It may not be amiss to climb the ladder all over again, if, when we look about, we find that we are in the wrong tree.

76. Drake Bakeries, Inc. v. Local 50, American Bakery Workers, 370 U.S. 254 (1962). aff'g 294 F.2d 399, rev'd on rehearing en banc 287 F.2d 155 (2d Cir. 1961).

77. 6 A CoRBIN \& 1443, at 436 (1962). 
the bargaining and had excused the employer from his duty to arbitrate. ${ }^{78}$ The union could not stay the employer's suit for breach of the no-strike clause, nor could it demand arbitration of the dispute which it had sought to resolve by strike. ${ }^{79}$ The Supreme Court, however, came to the opposite conclusion; ${ }^{80}$ and when another federal court followed suit ${ }^{81}$ Professor Corbin protested this judicial perversity:

How the court can hold that this Union's declared strike on February 7 was itself arbitrable is not understandable. Are all collective bargains to be taken wholly out of the law of contracts? Are employers the only parties who are bound? 82

This cry of outrage speaks faithfully from the body of legal rules and precedents which starts with the premise that "a general agreement to arbitrate all future disputes ... is contrary to public policy and void." 83 And it flows naturally from rules which Professor Corbin argued reflect a judicial distrust of the competency, objectivity, and fairness of arbitrators. ${ }^{84}$ A party who seeks to enforce a promise which is oppressive to the other party and distasteful to the courts will be required to walk the straight and narrow.

But quite opposite premises underlie labor arbitration. The Supreme Court has declared a preference for arbitration because the arbitrator's special competence is beyond that of the "ablest judge," and because of "the parties' confidence in his knowledge of the common law of the shop and their trust in his personal judgment." 85 When a union, as in Drake Bakeries, takes collective action to protest or counteract an employer's decision, the principles underlying the doctrine of material

78. Id. 440 .

79. Professor Corbin argued strongly in favor of the first decision of the Court of Appeals in Drake Bakeries. See also Local 721, United Packinghouse Workers v. Needham Packing Co., 254 Iowa 882, 119 N.W.2d 141 (1963).

80. After the Supreme Court decision, see note 76 supra, Professor Corbin partially recanted, acknowledging that there was a question whether the one-day abstention was a "strike" or even a breach of the agreement. The issue of breach vel non was, after all, within the coverage of the arbitration clause. Since the union's one-day abstention had been in the good faith belief that the employer had breached the agreement by ordering employees to work that day, there was no repudiation of the arbitration provision. But Professor Corbin held firm to his position that a forbidden strike barred the union from enforcing arbitration. 6A CoRBIN $\$ 1443$, at 47 (Supp. 1964).

The Supreme Court again disappointed Professor Corbin by overruling Needham Packing, supra note 79, 376 U.S. 247 (1964). As if to rub salt in his wounds, the Court quoted the paragraph in Drake Bakeries, 370 U.S. at 262-63, which had cited Professor Corbin's prior edition as its chief authority. 376 U.S. at 251-52.

81. Local 748, International Union of Electrical Workers v. Jefferson City Cabinet Co., 314 F.2d 192 (6th Cir. 1963).

82. 6A CORBIN \& 1443, at 49-50 n.33.5 (Supp. 1964).

83. 6 Corbin \& 1443, at 388 .

84. Id. at $392-94$.

85. United Steelworkers v. Warrior \& Gulf Navigation Co., 363 U.S. 574, 482 (1960). 
breach require the court to make a considered choice between the results which follow from ordering arbitration as against those which will follow from not ordering arbitration, and to determine which will be more conformable to justice in the particular case. Ordering arbitration works no injustice. Both the union's claim that the employer's rescheduling violates the collective agreement and the employer's claim that the union's preventing Saturday work violates the no-strike clause will be adjudicated by the tribunal which the parties have agreed was most competent and appropriate to interpret these provisions of the collective agreement. That tribunal has full power to order whatever remedy is appropriate to fulfill the purposes of the parties' agreement. Denying arbitration can, at best, transfer adjudication of these claims to the court-a tribunal which the parties agreed was second best, which has itself confessed its limited competence, and which has an independent interest in avoiding the burden of deciding such disputes. The more likely result of denying arbitration is that part or all of the dispute will never reach the deliberative judicial process but will be fought out with economic force in the form of strikes, discharges, and lockouts. Denying arbitration may serve to penalize the union-before it is decided that the union has violated the contract-at the expense of burdening the court and jeopardizing the social interest in stability of the bargaining relationship, with no advantages to the employer other than the possibility that the court will give him a better decision than he originally bargained for when he agreed to arbitration.

\section{Summary}

The law of contracts, so far as it consists of specific legal rules, analytical tools and manipulative doctrines, has little usefulness in application to collective agreements. Indeed, if the law of contracts does not go beyond this level of legal propositions, the law of collective agreements should insist on emancipation, if not disown family affiliation altogether.

The legal rules and doctrines discussed above are only illustrations which could be more than matched by examples drawn from contract law on offer and acceptance, consideration, joint and several contracts, liability of successors, or the Statute of Frauds. The specific contract rules in these areas, if not patently irrelevant or preposterous, are as likely to lead us astray as to guide us aright, and there is no magic to tell us which rules to trust. Analytical devices and doctrines appear to guide but can be used to point in any direction, and precedents based on different transactions too often point the wrong way. Sad experience 
has taught labor lawyers to distrust instinctively any arbitration or court opinion that cites the Restatement of Contracts or one of the classic treatises. If the law of contracts has nothing more to offer than black letter rules and precedent-burdened doctrines, the law of collective agreements will probably develop more sensibly if it is built as an independent body of law.

But the law of contracts must be more than this-the black letter of the Restatement, the confident propositions in treatises, and the traditional first year law school course notwithstanding. As we have already seen, the doctrine of material breach is analytically circular, verbally deceptive, and productive of misleading precedents. Underneath the words and precedents, however, that doctrine is a command to the courts to find the result which will be most conformable to justice in the particular case. The doctrine does not provide a mechanical answer, but it does free the court to weigh a broad range of considerations in determining a result. In all of the three cases discussed, Marathon Electric, Mastro Plastics, and Drake Bakeries, sensitive awareness of this underlying principle would have been helpful to the Court in making and articulating its decisions. This suggests the level at which the law of contracts may be useful to the law of collective agreements. It is to such principles that we now turn.

III. The Usefulness of Contract Law for Collective Agreements: Principles of Interpretation, Completion, and Revision

If we peel off the layers of specific rules and general doctrines we may find underneath certain basic principles of contract law which can make constructive contributions to the law of collective agreements. Professor Corbin has articulated at least some of those principles in a way which makes them particularly meaningful for labor lawyers. These principles, however, serve less as rules for deciding specific cases than as cautionary guards against reliance on rules. Perhaps their most practical function is to protect collective agreements from being victimized by bad contract law. The principles with which we deal here are those which guide the courts in interpreting, elaborating, and shaping the agreement of the parties.

\section{A. Interpretation, $A$ Task of Translation}

Collective agreements are expressed in the form of written documents, and the principles for interpreting written agreements are, of course, applicable in interpreting the words of collective agreements. 
But as Professor Corbin has so vigorously emphasized, the function of interpretation is to search for the meaning which the parties sought to express in the words used, to translate their words so as to achieve their intended result. ${ }^{86}$ The rules of interpretation are helpful only if they "lead to consideration of the various meanings of language that are worthy of comparison. They will be harmful if they are taken as dogmatic directions that must be followed, or if they mislead us into thinking that language has only one meaning, the one absolutely correct." 87 It was the simplistic dogmatism that words in a collective agreement could have only one true meaning, and that the meaning given to them by the judges, which underlay the Cutler-Hammer doctrine that if the judge saw no ambiguity in the provision of a collective agreement sought to be arbitrated, there was no "dispute" and, therefore, nothing to arbitrate. ${ }^{88}$ This doctrine, which had a crippling effect on labor arbitration, was repudiated by the Supreme Court in the Steelworkers Cases as the product of a "preoccupation with ordinary contract law," 89 in effect using the word "ordinary" as a synonym for "inapplicable."

One general principle of contract interpretation vigorously articulated by Professor Corbin is that meaning cannot be discovered "by poring over the words within the four corners of the paper." 90 Before a court can select one meaning in preference to other possible ones, "extrinsic evidence shall be heard to make the court aware of the 'surrounding circumstances,' including the persons, objects and events to which the words can be applied." 91 This principle of looking beyond the bare words to the surrounding circumstances is of fundamental importance in interpreting collective agreements. The words used may be common words which have uncommon meanings; the provisions are often sparsely stated without the adornment of definitions, qualifications, or specifications of scope; and the surrounding circumstances encompass the whole employment relationship-the processes of production, the history of the bargaining relationship, the past practices of the parties, and even the industrial jurisprudence which has evolved

86. For a demonstration of the inadequacy of linguistics to resolve disputes about the meaning of written contracts, see Young, Equivocation in the Making of Agreements, 64 Colum. L. Rev. 619 (1964). See also Farnsworth, "Meaning" in the Law of Contracts, 76 YALE L.J. 939 (1967); Sweet, Contract Making and Parol Evidence: Diagnosis and Treatment of a Sick Rule, 53 CoRnell L. REv. 1036 (1968); cf. Patterson, The Interpretation and Construction of Contracts, 64 Colum. L. Rev. 833, 845-46 (1964).

87. 3 Corbin \& 535, at 21 (1962).

88. International Ass'n of Machinists v. Cutler-Hammer, Inc., 271 App. Div. 917, 67

N.Y.S.2d 317, aff'd, 297 N.Y. 519, 74 N.E.2d 464 (1947).

89. United Steelworkers v. American Mfg. Co., 363 U.S. 564, 567 (1960).

90. 3 CorbIN \& 536, at 26 (1962).

91. Id. 28. 
under other bargaining relationships. The widespread preference for arbitration among parties to collective agreements stems in large measure from the fear that courts will be unwilling to look beyond the words of the agreement to this nearly unbounded field of surrounding circumstances, and that even if they are willing, they lack the competence to do so. The extravagant language in the Steelworkers Cases was a product of the Supreme Court's similar fears that judges would be unwilling or unable to give appropriate consideration to surrounding circumstances. In this respect, the Court's creation of a presumption in favor of arbitration expressed its belief that this basic principle of contract interpretation could and would be more faithfully followed by arbitrators than by the courts.

More narrowly, certain principles relating to the interpretation of integrated contracts and the application of the parol evidence rule have particular relevance for collective agreements. Arbitrators, like courts, are constantly bombarded by one party or the other with arguments that the parties' intent cannot be shown by extrinsic evidence unless the words of the agreement are ambiguous, or that parol evidence cannot be used to vary the plain meaning of the agreement. These arguments are invoked to exclude consideration of past practices, negotiating history, oral side agreements, or prior grievance settlements. But as Professor Corbin has so forcefully demonstrated, the meaning the parties intended to give the words cannot be known until one knows the circumstances surrounding their use of those words. Only then can it be determined whether the words are ambiguous or whether they have one plain meaning rather than another. ${ }^{22}$ The fact that an arbitrator or court, in looking at the naked words, can see only one meaning does not justify the imposition of that meaning on the parties. $^{93}$ In the words of Professor Corbin:

When it holds the parties bound in accordance with a meaning which seems "plain and clear" to the court and excludes convincing evidence that the parties gave the words a different meaning ... the court is making a contract for the parties which they did not make for themselves. ${ }^{94}$

\section{B. Completion, An Act of Creation}

Beyond these principles for determining the meaning which the parties intended is a basic counterprinciple of perhaps even greater

92. Id. \& 542.

93. Id. \& 539, at 80 .

94. Id. \& 542, at $111-12$. 
importance to the law of collective agreements-that the parties may be bound by a contract in ways they did not intend, foresee or understand.95 As Professor Corbin reminds us at the very beginning of his treatise:

The juristic effect (the resulting legal relations) of a man's expression in word or act may be very different from what he supposed it would be. The legal effects that are produced by an "agreement" depend upon past legislative and judicial history, of which men must be largely ignorant. They may depend also upon surrounding factors that are unknown to the parties and upon subsequently occurring circumstances that could not be known to anybody. ${ }^{96}$

Parties to a contract may, either intentionally or by oversight, omit certain terms or leave them to be determined in the future. When litigation ensues, the court, if it is not to frustrate the parties' dominant intent to make a contract, must often fill the gaps "if it is possible to reach a fair and just result." 97 Although courts declare that they will not make a contract for the parties, they must frequently complete the contract by filling in the omitted terms. Such completion is, in a very real sense, an act of creation.

One of the marked characteristics of collective agreements is their incompleteness, resulting in part from the failure of the parties to foresee or provide for many future problems, and in part from their inability to reach real agreement on certain issues which they do foresee. The counterprinciple that the binding effect of a contract is not rigidly circumscribed by what the parties had in mind when they signed it legitimates the exercise by arbitrators and courts of a creative function in completing the agreement. ${ }^{98}$ It invites inquiry beyond the often futile or artificial search for nonexistent intent and encourages explicit consideration of such factors as the purposes of the parties and the institutional needs of collective bargaining, justice and fairness between

95. Sweet \& Sweet, Architectural Cost Predictions: A Legal and Institutional Analysis, 56 CALIF. L. REv. 996 (1968); Farnsworth, Disputes Over Omissions in Contracts, 68 Colum. L. Rev. 860 (1968); Note, Requirements Contracts: Problems of Drafting and Construction, 78 HaRv. L. REv. 1212 (1965).

96. 1 CoRBIN \& 9, at 21 (1962).

97. Id. \& 95 , at 400 .

98. The alternative to completing a contract is declaring that no contract has been made. This may be a realistic alternative in other contractual relations, but it is an intolerable alternative in collective bargaining relationships. It would reopen all of the issues settled by prior bargaining and disrupt the entire relationship, almost guaranteeing economic conflict. The only realistic alternative is to preserve the existing agreement and leave the parties to bargain out the unsettled terms, with ultimate resort to a strike or lockout. But the presence of a no-strike clause commonly indicates that the parties themselves have rejected this alternative. Courts and arbitrators are then required to complete the agreement if it is to remain a viable institution. 
the parties, the interests of third parties, and the public interest. It also prevents preoccupation with the particular wording of the document and focuses more attention on the legal effect to be given the agreement. In weighing all of these considerations, the choice is made in terms of the results to be reached; the agreement is then completed or shaped to accomplish that result.

The problem of subcontracting may provide helpful illustrations. Consider the case of an employer who had done no substantial subcontracting in the past. When the union from time to time expressed fears for the future and suggested a no-subcontracting clause, the proposal was rejected as "unrealistic" and "borrowing trouble." As a result, discussions were inconclusive and the contract remained silent on the matter. Then during the contract term the employer announced that because of difficulties in keeping up on maintenance, it had subcontracted major repair, overhaul, and remodeling work. The union protested that this subcontracting violated the recognition and seniority clauses in the collective agreement and that the employer's unilateral action violated the recognition clause as well. The employer claimed reliance on the lack of a no-subcontracting clause and the words of the management rights clause.

An arbitrator, searching for intent in such a case, might pursue the shifting mirages thrown up by the contractual provisions or grope his way through the fog of negotiation history. But if he confronts squarely the necessity for completing the parties' agreement, given their failure to provide for or against subcontracting, he will be far more likely to seek, or more accurately to create, a result which will maximize the competing interests on both sides. With his search thus directed, he may find a solution which will protect the employees' job security, enable the employer to get the maintenance work done, establish a procedure which will increase the chance of discussion and agreement on future instances of subcontracting, avoid giving either party a bargaining advantage when it comes time to negotiate a contract and bargain out the unsettled issue, and reinforce the statutory policy that subcontracting is a mandatory subject of bargaining. ${ }^{99}$ The arbitrator must, of course, be conscious of his primary obligation to work the will of the parties and not replace their considered judgments with his. But the contract principle discussed here reminds him that he who acts as

99. Wallen, How Issues of Subcontracting and Plant Removal Are Decided by Arbitrators, 19 IND. \& LAB. REL. REv. 265 (1966); Korety, How Issues of Subcontracting and Plant Removal Are Handled by Courts, 19 Ind. \& LAB. Rel. Rev. 239 (1966); Dash, The Arbitration of Subcontracting Disputes, 16 IND. \& LAB. ReL. Rev. 208 (1962). 
judge must exercise judgment and he who completes must create. Collective agreements by their incompleteness impose on him the broad and heavy responsibility of performing a creative function. ${ }^{100}$

A similar subcontracting dispute was involved in United Steelworkers $v$. Warrior \& Gulf Navigation Company. ${ }^{101}$ The collective agreement contained a broad arbitration clause requiring arbitration of "differences . . . as to the meaning and application of the provisions of this Agreement" and "any local trouble of any kind," but also provided that "matters which are strictly a function of management shall not be subject to arbitration."102 The agreement contained no provision on subcontracting but did contain a management rights clause which stated that "direction of the working forces, including the right to hire, suspend or discharge for proper cause, or transfer, and the right to relieve employees from duty because of lack of work or for other legitimate reasons, is vested exclusively in the Company." The union protested that the company, by subcontracting out work that "could and has previously been performed by Company employees" while employees were laid off violated the agreement. The company answered that the subcontracting did not violate the agreement, because the company had subcontracted in the past and the union had failed in negotiations to obtain a clause limiting subcontracting. When the dispute between the parties could not be resolved by the grievance procedure, the union demanded arbitration of this "difference." The company refused, arguing that subcontracting was "strictly a function of management," and therefore not subject to arbitration.

The question before the Supreme Court was not whether the company had violated the agreement by subcontracting, but whether the

100. For an attempt to discern the principles to be applied by arbitrators in subcontracting cases, see Gross, Value Judgments in the Decisions of Arbitrators, 21 IND. \& LAB. REL. REv. 55 (1967). For a caveat by a leading arbitrator on how little the arbitrator's words may reveal of his abdominal cavity when he suffers from visceral jurisprudence, see Seitz, Communications, 21 Ind. \& LAB. ReL. Rev. 427 (1968).

101. 363 U.S. 574 (1960).

102. All of these clauses were contained in the two introductory paragraphs of the section on Adjustment of Grievances, and are stated below in their entirety.

Issues which conflict with any federal statute in its application as established by Court procedure or matters which are strictly a function of management shall not be subject to arbitration under this section.

Should differences arise between the Company and the Union or its members employed by the Company as to the meaning and application of provisions of this Agreement, or should any local trouble of any kind arise, there shall be no suspension of work on account of such differences but an earnest effort shall be made to settle such differences in the following manner.

There followed a five-step grievance procedure ending with:

Fifth, if agreement has not been reached, the matter shall be referred to an impartial umpire acceptable to both. . . . The decision of the umpire will be final. 
dispute between the parties should be decided by arbitration. This is, of course, a matter of contract, for arbitration must rest on the contract of the parties. This truism, however, can lead us astray if it smuggles in the premise that the contract is only what the parties had in mind when they used the words, for this premise pushes aside the basic contract principle that the courts must complete the contract and that this is an act of creation. ${ }^{103}$

The words of the arbitration clause quoted above may have a delusive simplicity until we look to the alternative legal effects which may be given to them. If the question whether the company violated the agreement by subcontracting cannot be decided by arbitration, it must be decided by the courts. To decide the dispute, the courts will have to scrutinize the substantive terms of the agreement, the past practices of the parties, and the bargaining history to determine what, if any, limitations the agreement places on subcontracting. Similarly, other disputes over whether the company by its actions has violated the agreement or kept within the sphere of management rights allowed by the agreement will not be decided by arbitration but by the courts. The result will be two categories of disputes, one decided by arbitrators and the other decided by judges, with no guide to distinguish the two except the self-defining phrase "matters which are strictly a function of management." To avoid this result, the arbitration clause might be read as requiring a court to make a preliminary inquiry to determine whether the company's action was clearly within its management function and to order arbitration only when the court found uncertainty-a contractual Cutler-Hammer rule. However, neither of these results fits comfortably within the broad wording of the arbitration clause, both conflict with the parties' apparent preference for the arbitration process, and both involve the courts in weighing the substantive merits of disputes. There is a third choice, to read the limiting clause as simply affirming that any matters which have been left wholly within management's discretion by the agreement shall not be subjected to any

103. Both the District Court and the Court of Appeals clearly decided the merits directly. Then having found for the employer on the merits, they found that the union had no right to arbitrate. In the District Court the conclusions of law, in sequence, were:

4. The labor contract does not prohibit, and is not susceptible of being interpreted

to require that defendant is prohibited from contracting out work.

5. The labor contract does not give the plaintiff or any of its members or any of the employees of the defendant the right to have arbitrated the question of whether the defendant may contract out work.

168 F. Supp. 702, 705 (S.D. Ala. 1958). The Court of Appeals, in affirming, followed the same sequence of reasoning. 269 F.2d 633 (5th Cir. 1959). 
qualifications through arbitration. The dispute whether the employer had discretion under the agreement to subcontract would be decided by the arbitrator who, if he found that the agreement gave the employer discretion, would not review the employer's actions.

In choosing which meaning to give the arbitration clause, the courts must weigh the legal effects and choose that meaning which most nearly achieves the results sought by the parties. But in this case such an approach only leads us to the gap in the agreement, for the parties did not make clear how the function of interpreting and applying substantive terms of the agreement should be allocated between the arbitrator and the courts. Indeed, the parties probably did not even clearly comprehend that the legal effect of excluding a category of disputes from arbitration was to allocate the power to decide those disputes to the courts.

Under such circumstances, contract principles require the court to complete the contract by choosing that result which will be consistent with the general framework of the parties' purposes and values as revealed by their agreement and their bargaining relationship. But contract principles also recognize that the court may properly give weight to considerations such as the court's lack of confidence in its own competence to decide such disputes, its interest in avoiding the burden of such cases, and its finding of a legislative policy favoring the arbitration process. ${ }^{104}$ These considerations were explicitly weighed by the Court in Warrior of Gulf and summarized in the shorthand expression that there is a presumption in favor of arbitrability. The dissent found this "an entirely new and strange doctrine," 105 but itself gave weight to considerations beyond the parties' intent. The dissent casts the balance in the opposite direction, relying on the traditional judicial hostility to arbitration ${ }^{108}$ expressed in the requirement that "the intention of the

104. Since the power to enforce carries with it the power to interpret, the legal concept of contract has come to include "not merely the agreement itself, but the entire body of law guiding its interpretation and enforcement so that official control becomes an integral part of the contract itself."

J.M. Clark, Social Control of Business 100 (2d ed. 1939). F. Kessler \& M. Sharp, Cases ANd Materials on Contracts 82 (1953).

105. 363 U.S. at 589 .

106. See 363 U.S. at $586-87$, and particulary the footnotes where language of previous decisions is italicized. After quoting Mr. Justice Cardozo's words, "our own favor or disfavor of the cause of arbitration is not to count as a factor in the appraisal of the thoughts of others," Marchant v. Mead-Morrison Mfg. Co., 252 N.Y. 284, 299, 169 N.E. 386, 391 (1929), the footnotes twice quoted other courts rejecting such professed neutrality with statements that the terms of the arbitration agreement "must be clear and unmistakable to oust the jurisdiction of the Court for trial by jury cannot be taken away in any case merely by implication." Continental Milling \& Feed Co. v. Doughnut Co., 186 Md. 669, 676, 48 A.2d 447, 450 (1946) (emphasis added by the Court). 
parties . . . should be made manifest by plain language."107 But both majority and dissent, despite their differences of result, were engaged in the creative function required by the contract principle under discussion. Both agreed, with greater or lesser degrees of candor, that the legal policy concerning arbitration should be given weight in choosing the legal effect to be given the agreement. They disagreed only on whether that legal policy favors or disfavors arbitration. ${ }^{108}$

\section{Revision, A Social Responsibility}

The contract principle that illegal bargains are unenforceable has particular significance for the law of collective agreements. The Labor Management Relations Act contains a number of express prohibitions against certain kinds of contract clauses. Section 8(e) prohibits "hot cargo" clauses, Sections $8(\mathrm{a})(3)$ and $8(\mathrm{~b})(2)$ restrict union security clauses, and Section 302 circumscribes welfare and pension plans. Provisions which violate these statutory prohibitions are obviously unenforceable between union and employer. And policies radiating from the statute impose other limitations on the collective agreement. An agreement made between an employer and a minority union is void if it purports to cover all employees, because it restrains the employees' rights of self-organization guaranteed by Section $7 .{ }^{109}$ Similarly, a provision in an agreement which is arbitrary as to any individual group of employees is void because it violates the union's duty of fair representation, a duty which derives from the union's status as exclusive representative. ${ }^{110}$ In short, the statutory structure establishes a framework within which the collective agreement is required to fit if it is to be legal and enforceable.

These specific examples serve to remind us that in making collective agreements, as in making other contracts, the parties are not completely free to make any agreement they wish. ${ }^{111}$ Free collective bargaining,

107. Quoted twice, 363 U.S. at 586 n.3, and 363 U.S. at 590, from U.S. v. Moorman, 338 U.S. 457, 462 (1950).

108. In theory, the courts might use an approach which would be neutral to arbitration. But when the issue is one of arbitrability, the simple question before the court is which tribunal, the court or the arbitrator, should adjudicate the dispute (assuming that the no-strike clause bars trial by combat). It is difficult to understand how the court can be wholly indifferent as to whether or not it is the tribunal to make the decision when it has important institutional interests at stake.

109. ILGWU v. NLRB, 366 U.S. 731 (1961).

110. Steele v. Louisville \& Nashville R.R., 323 U.S. 192 (1944); Syres v. Oil Workers, 350 U.S. 892 (1955); Hughes Tool Co., 147 N.L.R.B. 1573 (1964). Provisions of collective agreements may also be illegal under the antitrust laws, United Mine Workers v. Pennington, 381 U.S. 657 (1965).

111. See Lenhoff, Optional Terms (Jus Dispositium) and Required Terms (Jus Cogens) in the Law of Contracts, 45 MicH. L. REv. 39 (1946). 
like liberty of contract, is not an absolute; the parties' mutual desires may be defeated, trimmed, or shaped by overriding policies. ${ }^{112}$ These specific examples also serve to emphasize that collective agreements, because they are intimately affected by statutory provisions and policies, are more subject than most contracts to external restraints and guidance. Indeed, the presence of the statute and the public function of collective bargaining place on the courts an exceptionally heavy responsibility to decide when and how to impose restraints on the parties' agreements in order to give effect to the statutes' multiple policies, including the statutory policy of freedom of contract. Difficult as this task may be, the courts have no choice. To the famous statement, "Public policy is an unruly horse and dangerous to ride," Professor Corbin gave the unanswerable reply, "However unruly the horse may be, it is not possible for the courts to refuse to ride."113 We may criticize the courts for their horsemanship, but not for riding the horse on which contract principles place them. ${ }^{114}$

The responsibility of the courts for tailoring collective agreements to relevant policies ${ }^{115}$ may of course be achieved not only by excising provisions as illegal, but also by shaping through interpretation. ${ }^{116}$ The

112. For an illuminating and useful analysis of the various kinds of basic competing policies which courts must weigh in contract cases, see Macaulay, Justice Traynor and the Law of Contracts, 13 STAN. L. Rev. 812 (1961).

113. 6A CorbIN \& 1375, at $21 \mathrm{n} .9$ (1962). Professor Corbin emphasized his point by going on to say: "Justice (whether described as "natural" or artificial), public policy, general welfare, the settled convictions of mankind, community ideals, are all modes of describing substantially the same thing. It is this that the courts are established to administer and upon which in the last analysis their judgments are based." Id.

114. "The art of generalization on the basis of past experience, judicial or otherwise, is always a difficult one; and old doctrine continually requires amendment and 'restatement.' It is doubly difficult when climates of opinion on political or economic welfare are in flux. The judge then deserves our sympathy who must make a decision on the basis of 'public policy'; and he must expect our criticism after he makes it." 6A CoRBIN $\$ 1375$, at 14 (1962).

115. The arbitrator does not have the same responsibility or competence as the courts to give effect to statutory or other legal policies. The arbitrator is a creature of the contract; he is selected by the parties because they trust him to interpret and apply the contract; he owes his primary loyalty to the parties and to the improvement of their relationship; and he is often not legally trained. For these reasons he should not be expected to subject the parties' agreement to external restraints and guidance by applying legal and social policies other than those shared by the parties themselves. For a contrary view, see Blumrosen, Public Policy Considerations in Labor Arbitration, 14 RutGers L. REv. 217 (1960). The arbitrator does, of course, interpret and apply the agreement in the context of all of the values shared by the parties, and one of his functions is to accommodate and give expression to those values. This will inevitably require him to be responsive to many social and legal values beyond the conscious consideration of the parties. But he has little, if any, scope for overruling the parties' intent or common purposes by applying values not shared by them.

116. The term "interpretation" is a misnomer, for it does not rest on the mutual intent or purpose of the parties. Professor Corbin termed it "construction" to make the distinction explicit. But when the opinion is written, the rationalization is expressed in terms of intent even though it is an intent constructed by the court; and the court 
device of interpretation may, indeed, be preferable, for it can provide more flexibility in balancing other policies with freedom of contract. ${ }^{117}$ In Mastro Plastics, ${ }^{118}$ the collective agreement contained a broad and unqualified no-strike clause. When the union struck to protest the employer's gross unfair labor practices, the Supreme Court found in the bare words of the no-strike clause a conflict with the statutory policies of full freedom of association and self-organization. Instead of invalidating the clause, however, the court read the all-inclusive words of the no-strike clause "in the light of the law under which the contract was made," and found therein no prohibition against strikes to remedy such clearly unfair labor practices. The Court in effect rewrote the nostrike clause and still preserved freedom of contract by indicating that the parties could agree to bar such strikes. It simply required that such an agreement which encroached on statutory policies must be explicitly stated in the no-strike clause.

Similar balancing of statutory policies and freedom of contract was involved in Teamsters Local 174 v. Lucas Flour Company. ${ }^{110}$ The union struck to compel the reinstatement of an employee who had been discharged for unsatisfactory work. The collective agreement contained an arbitration clause requiring that disputes over discharges be submitted to binding arbitration, but did not contain a no-strike clause explicitly applicable to strikes over disputed discharges. ${ }^{120}$ The court

makes explicit that if the parties do make explicit a contrary intent, that intent will control.

117. For the use of both devices to curb the use and effect of provisions disclaiming warranties in the sale of goods, see Kessler, The Protection of the Consumer Under Modern Sales Law, 74 YALE L.J. 262 (1964); Von Hippel, The Control of Exemption Clauses: $A$ Comparative Study, 16 INT. \& CoMP. L.Q. 591 (1967).

118. 350 U.S. 270 (1956).

119. 369 U.S. 95 (1962).

120. This is the Court's characterization of the arbitration clause, but when the clause is closely scrutinized there is reason to conclude that the Court created an unreal case to pronounce a general principle. The arbitration and no-strike clauses were worded as follows:

Should any difference as to the true interpretation of this agreement arise, same shall be submitted to a Board of Arbitration of two members, one representing the firm and one representing the Union. If said members cannot agree, a third member, who must be a disinterested party shall be selected and the decision of said Board of Arbitration shall be binding. It is further agreed by both parties hereto that during such arbitration, there shall be no suspension of work.

Should any difference arise between the employer and the employee, same shall be submitted to arbitration by both parties. Failing to agree, they shall mutually appoint a third person whose decision shall be final and binding.

The first paragraph describes disputes between the union and the employer and arbitration between them. The second paragraph describes disputes between an employee and the employer and arbitration between them. The no-strike clause applies to all disputes described in the first paragraph, that is, collective disputes. The no-strike clause is missing from the second paragraph dealing with individual disputes, where by definition there is no "difference" between the union and the employer. The dispute which triggered 
upheld the employer's suit for damages for breach of contract, interpreting the arbitration clause as containing a co-extensive no-strike obligation. ${ }^{121}$

[A] strike to settle a dispute which a collective bargaining agreement provides shall be settled exclusively and finally by compulsory arbitration constitutes a violation of the agreement. . . . [A] contrary view would be completely at odds with the basic policy of national labor legislation to promote the arbitral process as a substitute for economic warfare. ${ }^{122}$

The court left the parties free to agree that the union might strike over disputes which were subject to arbitration, but required that if the parties wished to assert that freedom they must do so in explicit terms in the collective agreement. ${ }^{123}$ Obviously such a result affects the relative bargaining positions of the parties, for the burden is on the union to obtain a provision reserving the right to strike rather than on the company to obtain a provision prohibiting strikes. The dynamics of bargaining give this burden practical significance, for the bargaining advantage rests with the party who would leave the agreement un-

the strike was one between the union and the employer over whether the discharged employee's work had been "satisfactory" within the meaning of the discharge provision of the agreement. In short, the no-strike clause can be sensibly interpreted to prohibit the strike involved here; indeed, it required some obtuseness for the Court to feel compelled to read it otherwise.

121. It should be noted that under both paragraphs, arbitration was mandatory and the award was to be "binding." If the parties intended this provision to be legally enforceable, then it would seem that they did not contemplate that either party could take unilateral economic action to reverse an award. The award against the union can hardly be said to be "binding" if the union is not obligated to accept it and can strike for the opposite result. Such an award would be little more than advisory.

There is some question whether an arbitration clause which provides only for an advisory award is legally enforceable. The courts might properly refuse to entertain cases and issue orders compelling arbitration when either party might frustrate the process and overturn the decision by unilateral economic action. Arbitration under such circumstances would be unlikely to have sufficient therapeutic value as to justify the court's lending its efforts and prestige to the advisory process.

122. 369 U.S. at 105 .

123. There was no evidence in the record before the Court to show why the parties had worded the arbitration clause in the awkward way they did. The core of the dissent is that because the no-strike pledge is so common and so important, it is hardly probable that the parties would have overlooked it or left it to implication. This ignores the fact that the parties did include a no-strike clause and at most left ambiguous whether it applied to this dispute. Certainly, careful draftsmen would have made matters more explicit, but the whole section betrays the parties' clumsiness with words. There is nothing in the words or even any testimony in the record to suggest that the union intended when it agreed to the no-strike clause to reserve the right to strike when disputes involved interpretation and application of the discharge clause.

The inclusion of an arbitration clause without any express no-strike clause may be a deliberate ambiguity devised to enable the parties to sign a contract when they are unable to agree on this critical issue. For such a case, see W.L. Mead, Inc. v. Teamsters Local 25, 126 F. Supp. 466 (D. Mass. 1954), where the clause was drafted by the Massachusetts Commissioner of Labor to settle a troublesome dispute. 
changed, silent, or ambiguous. The weight of statutory policy was, in this measure, added to one of the parties' economic strength or bargaining power to favor the inclusion of a no-strike obligation.

This is not the place to discuss whether there is in fact a statutory policy of preserving the right to strike against unfair labor practices, as the Court found in Mastro Plastics, or whether there is a statutory policy of curtailing the right to strike over arbitrable grievances, as the Court found in Lucas Flour. Nor is this the place to discuss what weight the Court should give those statutory policies as against other policies, including freedom of contract. The central point here is that the Court in Mastro Plastics and Lucas Flour was doing that which was required of it by the contract principle underlying the law of illegal bargains. The dissent in Lucas Flour protested:

I had supposed ... that the job of courts enforcing contracts was to give legal effect to what the contracting parties actually do, not what the courts think they ought to do. ${ }^{124}$

But the courts' task is not that simple, for as Professor Corbin reminds us, no matter how unruly the horse of public policy, the courts are required to ride. ${ }^{125}$ To deny that they must and do ride only prevents them, and us, from critically examining their horsemanship. The need for critical examination of performance is particularly pressing in the case of collective agreements, because of the competing and sometimes conflicting statutory policies which envelop them. The court cannot hope to give proper effect and weight to those policies unless it clearly recognizes its function and faces it squarely. ${ }^{126}$

124. 369 U.S. at 108 (Black, J., dissenting).

125. Professor Kessler has stated the point more forcefully and more elegantly:

Thus in the evolution of the law of contracts, the basic assumption of the past that contract deals with the individual relations of men to each other has gradually given way to the realization that in large sectors of our social and economic life contract is no longer an individual and private affair, but a social institution affecting more than the interests of the two contracting parties. An analysis, therefore, of presentday contract exclusively in terms of volition and agreement does not do justice to contract as a social institution. Social control has become an integral part of contract itself, and cannot be omitted from any analysis of the modern law of contract.

F. Kessler \& M. Sharp, Contract Cases \& Materials 9 (1953).

126. Courts are not ideal institutions for performing this function, and schoolboy learning teaches that policy choices are for the legislature. Certainly this counsels the courts to tread softly in the area, but for them to refuse to perform this function altogether would be to reject an historically established responsibility. Indeed the history of Section 301 of Taft-Hartley suggests that the courts may do a more responsible and workable job of developing the law of collective agreements than Congress. That section, as written by Congress, left every significant question unanswered-what substantive law was to be applied, what remedies were to be available, whether state courts should be given jurisdiction, what role should be given to arbitration, and what role should be given the NLRB. The Court's performance in giving this vacuous section sense and con- 
To the extent that the court, by requiring explicit terms, favors one result rather than another, it changes the relative bargaining power of the parties. In the sense that it has interfered with the free play of market forces, the court has interfered with freedom of contract. The market in question, however, has already been closely structured by the statute, and the use of economic force has been tightly regulated by the law. The interference added by policy-oriented judicial interpretation is but gossamer in comparison with restraints imposed by the statutory duty to bargain and by limitations on secondary pressures. Furthermore, interpretation does not substitute the judgment of the court for the judgment of the parties if they have agreed on what is in their mutual self-interest. They need only make the result they seek adequately explicit. In the sense that they are free, within certain outer limits, to reach any agreement they mutually desire, freedom of contract remains unimpaired. Statutory policies become determinative only when the parties have failed to arrive at any clear resolution of their conflicting interests and desires.

\section{Summary}

The usefulness of contract law to collective agreements thus seems to be directly proportional to the generality of the legal propositions involved. As we have seen, detailed rules and even general doctrines are of little use, as often misleading as enlightening. The most useful legal propositions are the broad, nearly formless general principles which guide the interpretation of contracts, the function of the court in completing contracts, and the responsibility of the court to fit the agreement of the parties within the framework of overriding public policies. These principles quite obviously do not pretend to provide copybook answers to specific cases, but they do provide valuable guides to the facts to be examined and the considerations to be weighed in arriving at effective solutions.

These general contract principles have not been ignored in the law of collective agreements, although they are seldom identified as rooted in the law of contracts in arbitration and court opinions. Arbitrators customarily follow Professor Corbin's principles of interpretation without ever having read his treatise. They are seldom impaled on doctrines of integrated contracts or the parol evidence rule; they simply admit all evidence "for what it may be worth," and use it all to try to deter-

tent may be faulted, but it hardly demonstrates that the courts are less competent than Congress to perform this function, or that the courts should stay their hand until Congress has given guidance. 
mine what the parties intended. Professor Corbin would applaud their approach even while they studiously ignore contract law. Both courts and arbitrators recognize that they must fill the gaps in collective agreements and settle terms left unsettled. Even the Supreme Court has applied these principles with fair consistency and occasional boldness, while at the same time denigrating or disowning "ordinary contract law."

The law of collective agreements, therefore, does not need to borrow principles from the law of contracts; it needs only to acknowledge the debt it already owes. Such an acknowledgment would strengthen the law of collective agreements. Both courts and arbitrators would move with more confidence if they could feel that they were building on tested foundations; and they would move with better understanding and deeper insight if they could draw on the accumulated experience of courts in developing and applying underlying contract principles.

\section{The Usefulness of the Law of Collective Agreements for the Law of Contracts}

One who views contract law from the perspective of labor law, and whose last working contact with contract law was twenty years ago, should perhaps be cautious in venturing broad pronouncements on the subject. The risk is great that what may be said here will fall between the two stools of the obvious and the foolish. But collective agreements are contracts, though long treated as disowned offspring; and the law of collective agreements should have something to add to our understanding of the law of contracts.

At the most elementary level, the law of contracts could be enriched simply by drawing examples from the law of collective agreements to illustrate basic principles. A labor lawyer reading Corbin on Contracts cannot help regretting that Professor Corbin seemed unaware of how vividly his vigorously articulated principles were being demonstrated daily by arbitrators and courts in developing the law of collective agreements. Professor Corbin emphasized that all of our legal rules are only "tentative working rules" to be tested by experience and evolved as we more clearly perceive the problems to which we apply them. ${ }^{127}$ Could the law of contracts provide any better example than the continuing effort of the courts to work out their proper role in labor arbitration?

127. 1 CorbIN iv, v (1950); 1 id. \& 3; 3 id. § 535; 6A id. § 1375. See Kessler, Review, Corbin on Contracts, 61 Yale L.J. 1092 (1952). 
The Cutler-Hammer doctrine was tried, and when experience demonstrated its stultifying effect on the constructive role of labor arbitration, ${ }^{128}$ the Supreme Court, in the Steelworkers Cases, decisively repudiated Cutler-Hammer and set the law in a new direction. The evidence now available suggests that while the new rules have generally strengthened labor arbitration, ${ }^{129}$ those rules in turn need modifications. ${ }^{130}$ Wiley $v$. Livingston ${ }^{131}$ represented the first statement of tentative working rules to enable collective agreements to survive corporate mergers and consolidations-rules which are now in the process of being tested and reshaped. ${ }^{132}$ Lucas Flour represents a tentative rule on implied no-strike clauses, the value and workability of which can be tested only by experience. Humphrey v. Moore ${ }^{133}$ and Vaca v. Sipes ${ }^{134}$ are only two in a long series of attempts to develop working rules as to the rights of individual employees under collective agreements. Every labor lawyer who has a memory beyond last year's term of court can verify by multiple examples the truth and compelling relevance of Professor Corbin's central tenet.

When we go beyond the illustrative function of the law of collective agreements and attempt to integrate that body of law into the traditional structure of contract rules and principles, however, the elaborate edifice begins to crumble. There is no logical reason why we should not attempt such integration, for collective agreements are undeniably contracts, and the law of contracts, if it exists, should be able to absorb the law of collective agreements into its generalizations. When we actually attempt this integration, however, it is difficult to avoid the conclusion that the law of contracts, as commonly set forth in the Restatement and the treatises, is either fundamentally inadequate or an illusion.

128. See Summers, Judicial Review of Labor Arbitration or Alice Through the Looking Glass, 2 Buff. L. Rev. 1 (1952); Cox, Current Problems in the Law of Grievance Arbitration, 30 Rocky MT. L. Rev. 247 (1958); Wellington, Judge Magruder and the Labor Contract, 72 HaRv. L. Rev. 1268 (1959).

129. Jones \& Smith, Management and Labor Appraisals and Criticisms of the Arbitration Process: A Report with Comments, 62 Mich. L. Rev. 1115 (1964). Smith \& Jones, The Supreme Court and Labor Dispute Arbitration: The Emerging Federal Law, 63 MicH. L. REv. 751 (1965); Smith \& Jones, The Impact of the Emerging Federal Law of Grievance Arbitration, on Judges, Arbitrators and Parties, 52 VA. L. REv. 831 (1966).

130. Meltzer, Ruminations About Ideology, Law, and Labor Arbitration, $34 \mathrm{U}$. CHI.

L. Rev. 545 (1967); H. Wellington, Labor and the Legal Process 106-09 (1968).

131. 376 U.S. 543 (1964).

132. See Bath Iron Works Corp. v. Bath Marine Draftsmen's Ass'n, 393 F.2d 407 (1st Cir. 1968); Shaw \& Carter, Sales, Mergers and Union Contract Relations, in NYU NINEteenth ANn. Conf. on Labor 357 (1967); Note, 66 Colum. L. Rev. 967 (1967).

133. 375 U.S. 335 (1964).

134. 386 U.S. 171 (1967). 
Consider, just for a beginning, the difficulties of integrating into the law of third party beneficiary contracts the rights of individual employees under a collective agreement. Either most of the rules now stated with confident generality in treatises or in the Restatement would be fractured with qualifications and exceptions, ${ }^{135}$ or, more likely, the generalizations would continue to be stated with abstract purity and new sections would be added stating special rules for collective agreements. The only integration would be by the printer who bound the disparate sections within the same hard covers. Consider, in addition, restating the rules of damages to reflect the forms and uses of remedies now granted through arbitration for breach of collective agreements, adjusting the traditional rules of offer and acceptance to resolve problems that arise out of union procedures for membership ratification of agreements; or rewriting the rules governing the liability of successors and assigns so as to describe the legal consequences when one union replaces another as bargaining representative and when the consolidation of production units scrambles bargaining units. A new Restatement would obviously need to be undertaken and would, equally obviously, never be finished. The briefest consideration of the problems of attempting to integrate the law of collective agreements into the law of contracts makes us realize how inadequate our presently stated rules of contract law are for the task and how impossible it would be to restate them in a way to make them adequate. This, in turn, should make us wonder whether there may not be something basically defective in our present statement or even our conception of the law of contracts.

Our problems with the law of contracts multiply when we remember that the reasons traditionally given for treating collective agreements as something outside "ordinary contract law" are equally applicable to many other contractual transactions. Is the law of contracts as illequipped to deal with these other transactions as it is with collective agreements, although perhaps in different ways? What about long term requirements contracts, dealerships and franchises, restrictive covenants in deeds and long term leases of business properties, condominiums and cooperative housing arrangements, or even the common transaction of student registration in a university-how well do these fit within the presently stated contract rules? Put in more mundane but more prac-

135. See, e.g., the Court's struggle to restate the law of third party beneficiary contracts in Lewis v. Benedict Coal Co., 361 U.S. 459 (1960). The employer attempted to set off his damages resulting from the union's strikes in breach of the collective agreement against his liability to the pension and welfare fund. 
tical terms, would a lawyer or a judge find answers to problems arising out of these transactions in Corbin, Williston, or the Restatement? And if he found answers, would they be answers which would lead to satisfactory results? ${ }^{136}$

My uneasy suspicion is that lawyers dealing with problems arising out of such transactions find the law of contracts as inadequate as do the labor lawyers dealing with problems arising out of collective agreements. Certainly this seems to be the case with certain kinds of contractual transactions such as insurance, stock certificates, trust indentures, oil and gas leases, and ship charters. The difficulty of integrating the legal rules applicable to these transactions into the law of contracts is in practice neatly avoided by allocating them to separately named fields of law deriving their names from law school curricular labels or West Digest headings. Professor Corbin justified his pushing aside of collective agreements with the revealing assertion that " $[\mathrm{t}]$ hey cannot be treated with advantage separately from the general subject of Labor Relations and Labor Legislation."137 In the same way, it is commonly accepted that these other contractual arrangements "cannot be treated with advantage" separately from the general subject of the activity of which they are a part.

But if these kinds of contracts cannot be treated with advantage apart from the activity out of which they arise, may this not be true of all contracts? What is this "law of contracts" about which treatises and restatements are written? It almost seems to be the law of left-overs, of miscellaneous transactions, the rag-tag and bob-tail which do not get treated elsewhere. ${ }^{138}$ This is, of course, a caricature, but perhaps an instructive one.

A casual thumbing of the treatises and a glance at the factual situations described in the Restatement do little to dispel the impression that this caricature has much truth in it. The law of contracts, as there presented, is made up of rules which are worded as if they were applicable quite apart from any concrete circumstances. The rules are evolved from cases which tend to be stated without any particular reference to the background of the transactions involved, and thus give the impression of raising contract issues in their purest and simplest

136. For a colorful statement of the "ineffectuality of orthodox contract law" for significant commercial transactions, see Mooney, Old Kontract Principles and Karl's New Kode: An Essay on the Jurisprudence of Our New Commercial Law, 11 VILL. L. REv. 213, 254-56 (1966).

137. 6A CoRBIN \& 1420, at 345 (1962).

138. S. Macaulay, Law and the Balance of Power: The Automobile ManuFacturers AND Their Dealers 198 (1966). 
forms. ${ }^{139}$ The epitome of abstraction is the Restatement, which illustrates its black letter rules by transactions suspended in mid-air, creating the illusion that contract rules can be stated without reference to surrounding circumstances and are therefore generally applicable to all contractual transactions. In many of the illustrations the surrounding circumstances are not stated because they are so commonplace. Contracts to buy a car, to sell a house, to haul gravel, to employ a clerk, to grant a reward, to support a parent, or to make a will-in all of these we unconsciously supply stereotyped surroundings. In so doing, we are likely to forget how frequently those surroundings influence the result. Other illustrations seem to be of simple transactions-selling flour, shipping goods, publishing an advertisement, leasing a building, or guaranteeing payment of a debt-but they seem simple only because we do not know the surrounding circumstances and assume that there are no relevant business practices or complicating considerations. In all cases there is the silent assumption that if the circumstances are other than those assumed, the result may be different. Economic theories built upon the assumption of "other things being equal" may be useful, but detailed contract rules built upon the disclaimer "in the absence of special circumstances" are of limited utility in solving problems or building an integrated body of law capable of dealing effectively with the infinite variety of contractual transactions.

The law of contracts as presently conceived, therefore, cannot be expected to provide a framework for integrating the rules and principles applicable to all contractual transactions. Its generalizations are built largely upon selected cases considered to be "contract" cases by

139. “' 'Pure' contract doctrine is blind to details of subject matter and person. It does not ask who buys and who sells, and what is bought and sold. ... Contract law is abstraction-what is left in the law relating to agreements when particularities of person and subject-matter are removed." L. Friedman, Contract Law in America 20 (1965). Professor Friedman's analysis, if I understand it correctly, is that contract law originally consisted of legal rules reflecting the abstraction of the free market. As economic activities became regulated and transactions became subject to regulatory legal rules, contract law was displaced. "Pure" contracts are those which remain unregulated. In short, the legal rules of regulated transactions are not contract law.

This, it seems to me, looks through the telescope from the wrong end, for it narrows rather than broadens our vision. Contract law has always, in some measure, and in greater measure than most courts or scholars would openly acknowledge, regulated the content of the parties' agreement and injected social values into free market bargains. Both legislatures and courts have increasingly socialized contractual relations. One of the central goals of contract law should be to articulate what those social values are and how they become a part of the contractual relation. This requires our seeing the fundamentally common elements of contractual transactions, a vision which is not aided by casting out of contract law all of those transactions in which the regulatory aspect becomes visible. Professor Friedman would make contract law nearly synonymous with freedom of contract; I would make freedom of contract a significant but not absolute value in all contractual transactions. 
legal scholars, restatement writers, annotators, and indexers. This tends to exclude cases involving "special" transactions which can be treated more easily under other headings. The legal rules thus developed are not rules of general applicability; they are at most general rules adequate for regulating those transactions which are either not complicated enough or numerous enough to have stimulated the development of separate bodies of rules. From the perspective of collective agreements and other special contracts, the law of contracts presented in treatises and the Restatement is not a parent body of law but rather just another portion of the multifaceted law of contractual transactions. ${ }^{140}$

Having served the destructive purpose of discrediting the illusory unity of the law of contracts, the law of collective agreements ought at least to serve the constructive purpose of leading us to search for a more fundamental unity. Like the law of insurance contracts, the law of leases, the law of partnership agreements, and many other special contractual transactions, the law of collective agreements is a part of that amorphous field of law which might best be labeled the law of contractual transactions. Each of these categories has its own identity, for each has its own body of rules shaped by the special economic, social, institutional, and legal conditions surrounding the type of transaction with which it is concerned. If the "law of contracts" is to be conceived as encompassing all contractual transactions, it must not be conceptualized as a single body of law but as a family of bodies of law, interrelated but each distinctive. The study of contract law then becomes a study of comparative law.

Viewing contract law as an area for comparative study rather than as a unified body of law serves an immediate corrective purpose. It reduces the temptation to assume that a rule developed for one type of transaction is equally suitable for other types of transactions. It focuses our attention on the distinctive characteristics and surrounding circumstances of each type of transaction, and then encourages us to ask how particular rules respond to that distinctiveness. It encourages us, before borrowing rules or precedents from one setting, at least to inquire whether they will work the same results in the new setting. And in the

140. Professor Friedman seems to equate general contract law with transactions which retain nearly total freedom of contract, and splits off as specialized bodies of law those rules governing transactions which have been so regulated as to circumscribe freedom of contract. See note 139 supra. We might wish that legal categories had such philosophic rationality; but contract categories often have little more basis than the pragmatic reason that there are sufficient cases and statutes to make up a cluster of rules which some scholar, judge, or indexer can organize systematically. Even without legislative intervention insurance contracts, leases, sales warranties, and collective agreements would have developed their special bodies of law. 
process it directs our efforts more toward understanding the problem to be solved and weighing the results to be achieved than to searching for a particular rule to be applied.

Recasting the law of contracts as the comparative law of contractual transactions serves the larger intellectual purpose of suggesting where and how we are to search for unifying principles. We no longer expect to find common rules and principles except at the most basic level, framed in the most general terms. It would seem a reasonable guess, in fact, that the principles common to the whole range of contractual transactions are relatively few and of such generality and competing character that they should not be stated as legal rules at all. Indeed, they may be nothing more than a set of common problems radiating from centers of tension such as that between subjective and objective tests of agreement, between arms-length and fiduciary relations of the parties, and between freedom of contract and social control.

The most likely place to begin the search for unifying principles would seem to be those areas where we have already found contract principles useful in the law of collective agreements and where the law of collective agreements has seemed to follow those principles intuitively, or at least without articulate recognition. The pattern of decisions suggests the presence of working principles which are so deeply rooted that, even though unstated, they give direction to the development of legal rules. Beyond helping us identify established unifying principles, the law of collective agreements may suggest certain inchoate or emerging principles of general validity throughout the various bodies of contract law. In many respects the collective agreement is a paradigm of a planning transaction, consciously encouraged by law as an instrument both of private regulation and of social control. However, the law of collective agreements is at present so unformed and immature that few explicit underlying principles have emerged. Furthermore, the repeated disclaimers that collective agreements are contracts have discouraged articulation of principles in terms which would make them visibly relevant to other contractual transactions. Hence the suggestion that the law of collective agreements might contribute generally relevant principles to the law of other contractual transactions now serves only to tease the imagination.

Nevertheless, with the aid of a bit of that same imagination, we can perhaps see in the law of collective agreements the contours of certain basic contract principles, though often cloaked in special rules of labor law. A number of these cluster around the statutory duty to bargain in good faith. To be sure, that statutory duty serves quite special needs. It 
reinforces the right to organize by requiring the employer to recognize the majority union as the bargaining agent of his employees, and it encourages industrial peace by requiring the parties to engage in a process of reasoned discussions. ${ }^{141}$ These needs probably have few obvious counterparts in other contractual transactions. However, the duty to bargain does prescribe a standard of conduct for the parties in the making and carrying out of their agreement. The good faith required here by the statute may be akin to the good faith and fair dealing required in other contract situations by the courts. ${ }^{142}$ There are at least some intriguing resemblances. ${ }^{\mathbf{1 4 3}}$

In Fibreboard Paper Products Corp. $v . N L R B,{ }^{144}$ the employer and the union representing its employees in the maintenance department had a twenty-year bargaining relationship of successive collective agreements. The latest agreement was for one year, with automatic renewal unless one of the parties gave 60-day notice of a desire to modify or terminate. The union gave timely notice of a desire to modify and submitted its proposed modifications. The employer made no statement of its intentions and refused to meet with the union until four days before the end of the contract term. At that time the employer informed the union that it had decided to contract out its maintenance work, because this would be more economical than under the existing collective agreement and because the union in past years had resisted changes designed to reduce costs. The employer refused to bargain concerning its decision to subcontract and declared that because the subcontracting would result in dismissal of all employees represented by the union, any negotiations for a new agreement would be pointless. The Supreme Court upheld the Board's decision that the employer had violated its duty to bargain in good faith, and enforced the Board's order directing the employer to resume its maintenance operations and

141. See Wellington, Freedom of Contract and the Collective Agreement, 112 U. PA. L. REv. 467, 469-77 (1964).

142. Kessler \& Fine, Culpa in Contrahendo, Bargaining in Good Faith, and Freedom of Contract: A Comparative Study, 77 Harv. L. Rev. 401 (1964).

143. Compare the definition of "good faith" in the Dealers' Day In Court Act, 15 U.S.C. § 1221(e) (1964),

The term "good faith" shall mean the duty of each party to any franchise ... to act in a fair and equitable manner toward each other so as to guarantee the one party freedom from coercion, intimidation or threats of coercion or intimidation from the other party, Provided: That recommendation, endorsement, exposition, persuasion, urging or argument shall not be deemed to constitute a lack of good faith

with the definition in Section 2-103(1)(b) of the Uniform Commercial Code:

... honesty in fact and the observance of reasonable commercial standards of fair dealing in the trade.

144. 379 U.S. 203 (1964). 
reinstate the affected employees with back pay until it had made good faith efforts to reach an agreement with the union. The opinion is, of course, cast in the language of labor law, and the decision is supported by special statutory policies. But might not a contracts lawyer perceive, implicit in the opinion of the Court, familiar basic principles and some new thrusts of those principles? As an instrument of a continuing relationship the collective agreement necessarily contemplates continuity, with periodic renegotiations to meet changing situations. From the perspective of the contract principle of good faith and fair dealing, should one party to such a contractual relationship be permitted suddenly to declare it at an end as no longer economically viable, without giving the other party time to explore and accept changes which will make it viable? If we examined certain other continuing contractual relations, might we not find at least implicit this principle against abrupt and arbitrary terminations? ${ }^{145}$

The principle of good faith took a different form in NLRB v. Truitt Manufacturing Company. ${ }^{146}$ Again the union and the employer had an established bargaining relationship. When the union sought a wage increase of 10 cents per hour, the employer insisted that such an increase would put it out of business. The union asked for financial information to substantiate the claim so it could determine whether or not to press the demand for a wage increase. When the employer refused on the grounds that such information was not relevant to the bargaining, the union was placed in the position of either accepting the employer's assertion or calling a strike which would impose hardships on the employees and which would, if the employer were correct, prove futile and potentially self-destructive. The Supreme Court held that the employer, by asserting his inability to pay and then refusing to provide information to substantiate the assertion, had failed to bargain in good faith. Again, the Court's decision is set within a statutory framework; but the law of contracts recognizes several levels of the duty of one party to a contract to give relevant information to the other. ${ }^{147}$ Although many such cases smell of fraud, involving active or passive misleading, others involve only overreaching, particularly where there exists an

145. See, e.g., Dealers' Day in Court Act, 70 Stat. 1126 (1956), 15 U.S.C.A. \& 1222 (1964), allowing automobile dealers to recover damages from manufacturers who fail to act in good faith in performing or complying with the terms of the franchise or in terminating, cancelling, or not renewing it. State statutes have also limited the right to terminate or to refuse to renew. See Kessler, Automobile Dealer Franchises: Vertical Integration by Contract, 66 YAIE L.J. 1135, 1183 (1957); S. MACAULAY, supra note 138, at 92-164.

146. 351 U.S. 149 (1956).

147. See generally Kessler, The Protection of the Consumer Under Modern Sales Law, 74 Yale L.J. 262 (1964). 
established relationship which the courts may characterize as fiduciary. The contract principle of good faith and fair dealing has shown some impatience with parties who would turn contract-making into a game of blindman's buff. ${ }^{148}$ In Truitt, where the employer put the union to an oppressively hard choice by withholding crucial information, the response of the Court should have a familiar ring in a contract lawyer's ears:

Good faith bargaining necessarily requires that claims made by either bargainer should be honest claims. This is true about an asserted inability to pay an increase in wages. If such an argument is important enough to present in the give and take of bargaining, it is important enough to require some proof of its accuracy. ${ }^{149}$

There may well be other contractual relations in which the principle of fair dealing has been or should be extended to impose a duty to share information which will facilitate the reaching of an agreement, limiting the use of access to information as a bargaining lever.

The duty to bargain may also contain an element of protection against overreaching. In NLRB $v$. Wooster Division of Borg-Warner Corporation, ${ }^{150}$ the employer refused to enter into an agreement unless it included a provision that the union would not strike on non-arbitrable issues except after a secret ballot vote by all employees, union and non-union. The effect would have been to remove the decisionmaking power from the union in derogation of its statutory rights as exclusive representative. The union, of course, found this wholly unacceptable; but after two months of bargaining and a six-week strike, it surrendered and signed such an agreement under protest. The Supreme Court held that, although the clause was lawful, for the employer to insist upon it as a condition of making an agreement was a violation of the statutory duty to bargain in good faith. The employer could propose such a clause and try to persuade the union to agree, but could not use its economic bargaining power to compel the union to accept it. ${ }^{151}$ Although the Court rationalized its decision in terms of

148. Proposals for consumer protection legislation are largely directed toward requiring disclosure even though there is no fraud in the traditional sense. For example, lenders may be required to disclose the full interest charges in terms of annual rate so as to be readily understandable to the borrower. See Jordan \& Warren, The Uniform Consumer Credit Code, 68 Colum. L. Rev. 387 (1968). It is also proposed that sellers label goods and price them in a way which will permit buyers to make shopping comparisons. See Note, Consumer Legislation and the Poor, 76 YAlE L.J. 745, 773 (1967); see also Note, Disclaimers of Warranty in Consumer Sales, 77 HARv. L. REv. 318 (1963).

149. 351 U.S. at 152-53.

150. 356 U.S. 342 (1958).

151. A central purpose of the labor relations statutes was to "equalize bargaining power" by creating collective economic strength on the employees' side to match the 
"mandatory subjects of bargaining," a contracts lawyer might be excused for feeling that this was an inadequate description of the underlying principle against overreaching or unconscionable contracts. ${ }^{152}$

This is not the simplistic argument that the duty to bargain is only a transposition to labor law of contract principles, or that the duty to bargain can be extrapolated to other contractual transactions. That would be inadequate labor law and irresponsible contract law. The duty to bargain is designed to meet the special needs of a special contractual process, in which there is special social concern to avoid the disruption caused by non-agreement. The legal rules governing other types of transactions must be tailored to fit the special characteristics of those transactions and the social concerns involved. That is the central significance of viewing the law of contracts not as a unity but as a field of comparative law. This, however, does not foreclose the possibility that there may be certain broad unifying principles running through the various bodies of contract law and that the law of collective agreements may help illuminate them. All that is suggested here is that some of these principles may be reflected in the statutory duty to bargain, with full realization that a closer look might show the reflections to be deceptive shadows of quite different principles.

Labor arbitration decisions display the impact of broad contract principles much more plainly than do judicial decisions in labor cases. For example, in deciding subcontracting cases, arbitrators may find implied limitations in the recognition clause, the seniority clause, or negotiation history. But running through many of the cases is the principle that the union, having won benefits through hard bargaining, should not have those benefits depreciated by the employer's moving

collective economic strength on the employers' side. The statutes, however, cannot insure that the countervailing powers will always balance. At times, one can and does overwhelm the other. Many of the duty-to-bargain cases dramatically illustrate the real danger of the stronger party overreaching and imposing unconscionable procedures or provisions on the other. Some collective agreements might well be described as contracts of adhesion. See Kessler, Contracts of Adhesion-Some Thoughts About Freedom of Contract, 43 Colum. L. REv. 629 (1943). The most noted example is the standard form contract used by the Musicians, but standardized agreements are commonly used by the Teamsters and other unions who deal with large numbers of small employers who do not belong to employers' associations.

152. See 1 CoRBIN $\& 128$ (1963). This principle has received statutory expression in Section 2-302 of the Uniform Commercial Code, which has in turn seeded a thunderstorm of contentious articles. See, e.g., Braucher, Sale of Goods in the Uniform Commercial Code, 26 LA. L. REv. 192 (1966); Leff, Unconscionability and the Code-The Emperor's New Clause, 115 U. PA. L. Rev. 485 (1967); Note, Bargaining Power and Unconscionability: A Suggested Approach to U.C.C., Sec. 2-302, 114 U. PA. L. REv. 998 (1966); Note, Commercial Decency and the Code-The Doctrine of Unconscionability Vindicated, 9 WM. \& MARY L. Rev. 1143 (1968). 
work out of the area covered by the agreement. ${ }^{153}$ The extensive reliance by arbitrators on past practice ${ }^{154}$ also reflects the importance of this principle that one party to a contract shall not by his conduct deprive the other of the value of his bargain. ${ }^{155}$ Such principles may be used more freely and explicitly by arbitrators than by judges because of the arbitrator's sense of freedom from confining contract rules, and also because of the necessity of explaining his result in elementary terms of fairness. The evolving law of collective agreements may, therefore, not only serve to illuminate these principles but also provide the cutting edge for their further development and expansion.

The innovative character of labor arbitration is naturally conducive to the development of principles which may reach beyond the law of collective agreements. For example, labor arbitrators seem to have evolved a broad principle of procedural regularity, particularly in the parties' dealings with one another during the term of the relationship. If the agreement provides that the employer may change shift schedules, transfer employees, or create new job descriptions after discussion with the union, changes effected without prior discussion are commonly declared void even though there has been no substantial injury. An employee who is given an improper order must obey and process his protest through the specified grievance procedure, even though this gives him no effective redress. Failure to notify the union prior to a discharge, where that is required by the agreement, will lead to reinstatement of an employee, regardless of his guilt. Such results do not exalt procedure over substance but rather assert that procedure is an essential part of the substance of a continuing contractual relationship such as collective bargaining.

Arbitrators have also imported into collective agreements certain procedural safeguards in the name of fundamental fairness. ${ }^{156} \mathrm{Em}$ ployees cannot be disciplined for conduct which they were not clearly

153. See Wallen, How Issues of Subcontracting and Plant Removal are Handled by Arbitrators, 19 IND. \& LAB. REL. Rev. 265 (1966); Dash, The Arbitration of Subcontracting Disputes, 16 Ind. \& LAB. REL. Rev. 208 (1962); Greenbaum, The Arbitration of Subcontracting Disputes: An Addendum, 16 IND. \& LAB. ReL. Rev. 221 (1962).

154. Mittenthal, Past Practice and the Administration of Collective Agreements, in arbitration and Public Policy, Proceedings, fourteenth Annual Meeting, National Academy of Arbitration 30 (1961); B. Aaron, The Uses of the Past in Arbitration, in Arbitration TODAY 11 (1955).

155. Farnsworth, Good Faith Performance and Commercial Reasonableness Under the Uniform Commercial Code, 30 U. CHI. L. Rev. 666 (1963); Mooney, supra note 136, at 244-53.

156. Cf. Professor Macaulay's thesis that in the automobile dealer franchise situation the concepts of due process have been used to give content to imprecise statutes and to provide protection to the dealers. S. MACAulay, supra note 138, at 189-97. 
aware was punishable, or for violation of rules not regularly enforced. Employees must be clearly informed of the reasons for discipline, they must be allowed to consult a union steward immediately, they must be confronted with the evidence against them, and their guilt must be clearly proven. ${ }^{157}$ Rules against improperly obtained evidence, selfincrimination, and double jeopardy are often enforced. ${ }^{158}$ All of this is done to protect the continuing employment relationship from abrupt termination. ${ }^{159}$

These and other principles which one sees, or imagines he sees, at work in labor arbitration, or in cases delineating the statutory duty to bargain, will not provide precedents for deciding cases involving other contractual transactions. But if we can identify contract principles underlying collective agreements, it may help us recognize those principles operating in other contracts. More important, it may give us clearer insight into the nature and limitations of the principles themselves, and into the scope and effects of their application to various types of contracts. This will in turn carry us a step further toward restating the law of contracts as a collection of general principles, often overlapping or competing, which unify the field of consensual arrangements.

\section{Conclusion}

We have travelled far from Professor Corbin's dismissal of the collective agreement as not an "ordinary bargain of commerce" and relegation of its treatment to "the general subject of Labor Relations and Labor Legislation." We end with the conclusion that his attitude reflected not only a failure to recognize the nature of collective agreements but also a failure to recognize the nature of the law of contracts. He deprived the law of collective agreements of the benefits which his forcefully articulated principles would have provided, and deprived himself of the insights which the law of collective agreements might have contributed.

If these conclusions are well-founded, Corbin on Contracts seems almost to be a massive misdirection of effort. The major bulk of it is

157. See generally M. Stone, Labor Management Contracts at Work ch. 10 (1961).

158. R. Fleming, The Labor Arbitration Process ch. 7 (1965).

159. Neither courts nor legislatures have provided even the shadow of such protection of the employment relationship in the absence of a collective agreement, although the need is obvious and the legal doctrines available. For an excellent analysis see Blades, Employment at Will vs. Industrial Freedom: On Limiting the Abusive Exercise of Employer Power, 67 Colum. L. REv. 1404 (1967). 
composed of detailed rules applicable to only a limited range of transactions: it sets forth not the law of contracts but only the rules of law for some contracts. Professor Corbin, however, perhaps more than anyone else, recognized the impossibility of stating firm rules applicable to all situations. He stated at the very outset:

In the huge societies of today, transactions are continually escaping from old forms and patterns; and opinions of social policy and general welfare are affected by the conflicts among larger groups struggling for a greater share in the objects of desire. New classifications are continually required; and old classifications continually limited or replaced. ${ }^{160}$

He devoted years of labor to analyzing decisions, distilling detailed rules and setting them down in a systematic structure, but at the same time he repeatedly disclaimed any intent or hope to state crystallized rules. $\mathrm{He}$ insisted that his rules were tentative working rules, not "dogmatic directions to be followed," and he labored nearly as hard to demonstrate the uncertainty of the rules as he did to state them. His great work was, at one and the same time, a treatise and an anti-treatise, with a seeming inner contradiction as to the reason for its creation. Perhaps if Professor Corbin had seen collective agreements from the perspective presented here, and had accepted the implications of that perspective, he would have emphasized the anti-treatise and left the more pedantic work of treatise writing to those less creative than himself.

160. 1 CoRBIN \& 3, at 7-8 (1963). 